\title{
Note
}

\section{Emergency Power and the Militia Acts}

\author{
Stephen I. Vladeck
}

\author{
CONTENTS
}

INTRODUCTION

I. The First Militia ClaUSE AND THE Militia ACTS.......................... 156

A. The Constitution and Emergency Power .................................. 156

B. "Calling Forth" the State Militias: The 1792 and I795 Militia Acts.

C. "Caliing Forth" the Federal Army: The 1807 and 1861 Acts.

D. Martial Law, Habeas Corpus, and the Ku Klux Klan................. 167

II. The Militia ACTS, THE COURTS, AND EMERGENCIES ..................... 169

A. Martial Law in the Early Republic: Mott and Luther................. 170

B. Emergency Power During the Civil War ................................... 175

1. The Militia Acts and Martial Law: Field and the Trigger Problem .................................................. 175

2. The Importance of the Prize Cases ...................................... 177

3. Milligan and a Suggested Trigger ....................................... 180

C. The Problem of "Inherent" Presidential Power:

Debs and Neagle 183 
III. The Militia ACts, EMERgenCy PowER, AND THE ACADEMY ........ 186

A. Corwin, Fairman, and the Misreading of the Prize Cases........... 186

B. Steel Seizure, the Misunderstanding, and Emergency

Power Today ...................................................................... 190

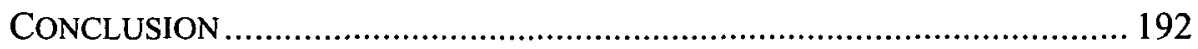


The accretion of dangerous power does not come in a day. It does come, however slowly, from the generative force of unchecked disregard of the restrictions that fence in even the most disinterested assertion of authority. ${ }^{1}$

\section{INTRODUCTION}

Terrorist cells in Brooklyn carry out an escalating series of terrorist attacks on New York City over the course of several weeks. After the third such attack, which destroys the FBI's New York headquarters and kills hundreds, the President declares a state of martial law in Brooklyn, imposes a curfew, rounds up individuals of Middle Eastern descent, and subjects the borough's two-million-plus residents to harsh, restrictive military ruleincluding the torture of several suspects-until the remaining cells are hunted down and destroyed. Borrowed from the eerily prescient 1998 movie The Siege, ${ }^{2}$ this scenario raises some extraordinarily serious and difficult legal questions.

Among them, what are the limits of such executive military authority, insofar as both time and scope of power are concerned? Are there any? Can there be any? What role can courts, if they are even open, play during such a crisis? What remedy is there for violations of whatever constitutional mandates still apply? Who gets to say when the crisis is over? Most importantly, where would we start, the morning after, in trying to answer these questions, or even in trying to pose them?

Many contemporary scholars argue either that most emergency powers described above are inherently executive (because they follow from the Vesting Clause, the Oath Clause, the Commander-in-Chief Clause, or the Take Care Clause) ${ }^{3}$ or are extraconstitutional (i.e., they apply when the Constitution does not). ${ }^{4}$ Invoking the specter of Jefferson ${ }^{5}$ or Lincoln, ${ }^{6}$

1. Youngstown Sheet \& Tube Co. v. Sawyer (Steel Seizure), 343 U.S. 579, 594 (1952) (Frankfurter, J., concurring).

2. THE SIEGE (20th Century Fox 1998); see also Kirk L. Davies, The Imposition of Martial Law in the United States, 49 A.F. L. REV. 67, 111 (2000) (invoking The Siege as a hypothetical).

3. For a summary of this argument, see DANIEL FARBER, LINCOLN'S CONSTITUTION 127-29 (2003). See also Henry P. Monaghan, The Protective Power of the Presidency, 93 COLUM. L. REV. 1, 38-61 (1993) (detailing the evolution of this theory of presidential authority).

4. See, e.g., Oren Gross, Chaos and Rules: Should Responses to Violent Crises Always Be Constitutional?, 112 YALE L.J. 1011, 1096-133 (2003). See generally George Winterton, The Concept of Extra-Constitutional Executive Power in Domestic Affairs, 7 HASTINGS CONST. L.Q. 1 (1979) (providing an overview of the theory and its origins).

These arguments are closely aligned with arguments in favor of "constitutional dictatorship." As Martin Sheffer puts it, "Occasionally, the Constitution must be suspended so that it might not be permanently destroyed. If this means that some form of constitutional dictatorship is inevitable, in order for the nation to survive and then continue as a democracy after the emergency is over, so be it." Martin S. Sheffer, Does Absolute Power Corrupt Absolutely? Part I. A Theoretical Review of Presidential War Powers, 24 OKLA. CITY U. L. REV. 233, 246-47 (1999) (emphasis and 
many writers today seem content with the assumption that, whether such authority is extraconstitutional, there is little question that the bulk of emergency power belongs exclusively to the Executive, and that the Constitution, to whatever degree it speaks to the issue, does not suggest otherwise. ${ }^{7}$ Lost in this ongoing exchange about the government's crisis authority, however, are two basic questions: What emergency powers does the Constitution actually provide, and in which branches are they vested? ${ }^{8}$

This Note takes up these questions in the specific context of a vital subset of emergency powers: the power to use military force in responding to domestic crises, including the imposition of martial law. It suggests that the contemporary understanding, at least insofar as it holds that most constitutional emergency powers belong to the Executive, fails to account for this important area. Specifically, the Note argues that this subset of presidential emergency power is traceable to a series of statutes passed by Congress in 1792, 1795, 1807, 1861, and 1871. "These "Militia Acts,"

footnotes omitted); see also CLINTON L. ROSSITER, CONSTITUTIONAL DiCTATORSHIP: CRISIS GOVERNMENT IN THE MODERN DEMOCRACIES 288-314 (1948).

5. Letter from Thomas Jefferson to John B. Colvin (Sept. 20, 1810), in 11 THE WORKS OF THOMAS JEFFERSON 146 (Paul Leicester Ford ed., 1905) ("To lose our country by a scrupulous adherence to written law, would be to lose the law itself, with life, liberty, property and all those who are enjoying them with us; thus absurdly sacrificing the end to the means."), quoted in Jules Lobel, Emergency Power and the Decline of Liberalism, 98 YALE L.J. 1385, 1393 (1989).

6. As Lincoln famously asked Congress with regard to the Suspension Clause, "[A]re all the laws, but one, to go unexecuted, and the government itself go to pieces, lest that one be violated?" Abraham Lincoln, Message to Congress in Special Session (July 4, 1861), in 4 THE COLLECTED WORKS OF ABRAHAM LINCOLN 421, 430 (Roy P. Basler ed., 1953).

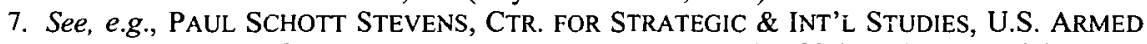
FORCES AND HOMELAND DEFENSE: THE LEGAL FRAMEWORK 4-8 (2001); Robert J. Delahunty \& John C. Yoo, The President's Constitutional Authority To Conduct Military Operations Against Terrorist Organizations and the Nations That Harbor or Support Them, 25 HARV. J.L. \& PUB. POL'Y 487, 488-89, 515-17 (2002). For a recent examination of martial law largely overlooking questions as to its source, see Jason Collins Weida, Note, A Republic of Emergencies: Martial Law in American Jurisprudence, 36 CONN. L. REV. 1397 (2004).

8. In the most recent colloquy over emergency power, these issues were brushed aside. Compare Bruce Ackerman, The Emergency Constitution, 113 YALE L.J. 1029 (2004) [hereinafter Ackerman, Emergency Constitution], and Bruce Ackerman, This Is Not a War, 113 YALE L.J. 1871 (2004), with David Cole, The Priority of Morality: The Emergency Constitution's Blind Spot, 113 YALE L.J. 1753 (2004), and Laurence H. Tribe \& Patrick O. Gudridge, The AntiEmiergency Constitution, 113 YALE L.J. 1801 (2004). The exchange between these scholars is instructive, both for the extent to which they grapple with poignant questions about emergencies facing Western democracies after September 11, and also for the surprisingly little attention they give to any arguments about constitutional structure and where Ackerman's proposal would fit in.

9. The five statutes are the Calling Forth Act of 1792, ch. 28, 1 Stat. 264 (repealed 1795); the Militia Act of 1795 , ch. 36 , 1 Stat. 424 (repealed in part 1861 and current version at 10 U.S.C. $\S \S$ $331-335(2000)$ ); the Insurrection Act of 1807 , ch. 39, 2 Stat. 443 (current version at 10 U.S.C. $\$ \S$ 331-335 (2000)); the Suppression of the Rebellion Act of 1861, ch. 25, 12 Stat. 281 (current version at 10 U.S.C. $\S \S 331-335$ (2000)); and specific parts of the Ku Klux Klan (Civil Rights) Act of 1871 , ch. $22, \S \S 3-4,17$ Stat. 13, 14-15 (expired in part 1873 and current version at 10 U.S.C. $\S 333$ ). Though each of the statutes is known by a host of different names, I use these names, the most common form for each, throughout this Note, and I refer to them collectively as 
enacted largely pursuant to Congress's authority under the First Militia Clause "[t]o provide for calling forth the Militia to execute the Laws of the Union, suppress Insurrections and repel Invasions," 10 delegated broad swaths of emergency power to the President, especially the power to impose martial law and suspend the writ of habeas corpus during serious internal crises.

As the Note demonstrates, early practice and what little relevant case law there is further bear out this thesis. Although this body of constitutional emergency power today belongs to the Executive, it is not because of the constitutional authority provided by Article II, but rather because of congressional delegation. Though the separate issue of extraconstitutional emergency power is beyond the scope of this Note, it bears emphasizing that the history this Note traces suggests that, though the time may come when some heretofore unforeseeable crisis or disaster requires resort to extraconstitutional measures, it hasn't yet.

To be clear, the argument is not that all (or even most) emergency power is traceable to the Militia Acts; over time, Congress has enacted hundreds of statutes specifically meant to prescribe-or proscribe-various types of crisis authority, and most have little or nothing to do with the military. ${ }^{11}$ But the power to suspend civil law and impose martial rule is undoubtedly among the most serious and drastic measures the government can take in an emergency, and to the extent that this Note demonstrates how even this extreme type of crisis authority is textually and historically committed to Congress, it no doubt informs arguments about the constitutional sources of other, lesser forms of emergency power.

An obvious question at the outset is why the constitutional source of such power should matter to modern scholars if Congress has delegated nearly all of its authority in this particular area to the President. The answer is threefold: First, because this immensely significant form of emergency power is legislative, Congress can by statute regulate and circumscribe its limits-what Congress giveth, Congress can surely taketh away. Whatever infirmities there may be with the current statutory regime governing such crisis authority - and this Note suggests there are several-Congress can, and indeed should, address them through appropriate legislation.

the "Militia Acts," even though the name is a bit of a misnomer, especially after 1807. See infra notes 61-68 and accompanying text.

10. U.S. CONST. art. I, § 8, cl. 15 ; see also Selective Draft Law Cases, 245 U.S. 366, 382-86 (1918) (discussing the First and Second Militia Clauses); Frederick Bernays Wiener, The Militia Clause of the Constitution, 54 HARV. L. REV. 181 (1940) (same).

11. For a partial survey of these statutes, see SPECIAL COMM. ON NAT'L EMERGENCIES \& Delegated EMERgency Powers, A ReCommended National EMERGencies ACT, S. ReP. No. 93-1170, at 2-3 (1974). See also infra notes 183-188 and accompanying text. 
Second, the fact that the Constitution vests even the power to impose martial law in Congress calls into serious question presidential claims to broad unilateral power during emergencies. Thus, in order to preserve the structural allocation of emergency powers envisaged by the Founders and early Congresses, courts must subject independent actions presidents undertake in emergencies to exceptionally rigid scrutiny to determine whether Congress has provided authorization. The most prominent contemporary example of this is the Padilla case, where, leaving aside procedural issues, ${ }^{12}$ the debate centered on whether the President has constitutional authority to hold a U.S. citizen suspected of terrorist ties and detained on U.S. soil without being charged, or whether statutory authorization is necessary and, if so, whether it is present. ${ }^{13}$

Finally, the notion that the Constitution, via the First Militia Clause and various other provisions, vests broad emergency military power in Congress to delegate as it sees fit calls into question the arguments of many modern scholars of emergency, and it suggests that our traditional assumptions about governmental crisis authority in the United States took a wrong turn sometime in the past. The questions are when, and why?

The Note begins in Part I with the Founding and the statutes, tracing the role of Congress in legislating military emergencies from what the Framers intended in 1787 to how Congress asserted itself in the Acts passed in 1792, $1795,1807,1861$, and 1871. In recounting the history of and interplay between these five statutes, Part I shows that the Founders and early Congresses agreed that the Constitution gives most authority over military emergencies to the legislature, to delegate at its discretion.

In Part II, the Note turns to the evolution of conceptions of emergency power in both the executive branch and the judiciary. Centering on the four nineteenth-century Supreme Court decisions that prominently discussed the question of emergency power, ${ }^{14}$ Part II demonstrates that the early Court,

12. See Rumsfeld v. Padilla, 124 S. Ct. 2711 (2004).

13. See Padilla v. Rumsfeld, 352 F.3d 695 (2d Cir. 2003), rev'd on other grounds, 124 S. Ct. 2711. For a survey of the issues arising out of the detention of U.S. citizens as "enemy combatants," see Stephen I. Vladeck, Note, The Detention Power, 22 YALE L. \& POL'Y REV. 153 (2004). See also Hamdi v. Rumsfeld, 124 S. Ct. 2633, 2653-59 (2004) (Souter, J., concurring in part, dissenting in part, and concurring in the judgment). In his Hamdi opinion, Justice Souter suggested that "in a moment of genuine emergency, when the Government must act with no time for deliberation, the Executive may be able to detain a citizen if there is reason to fear he is an imminent threat to the safety of the Nation and its people." Id. at 2659. But as Justice Scalia argued, any emergency detention power must come through congressional suspension of habeas, see id. at 2664-65 (Scalia, J., dissenting), and this Note suggests that in a true military emergency, the suspension of the writ is necessarily part of martial law, which Congress, through the Militia Acts, has given the President the power to impose.

14. The four cases on which Part II's analysis heavily relies are Martin v. Mott, 25 U.S. (12 Wheat.) 19 (1827); Luther v. Borden, 48 U.S. (7 How.) 1 (1849); the Prize Cases, 67 U.S. (2 Black) 635 (1863); and Ex parte Milligan, 71 U.S. (4 Wall.) 2 (1866). 
and most early presidents, viewed the power to call out the militia as a major aspect of emergency power generally and often spoke of one when invoking the other. Particularly in its decisions in these landmark nineteenth-century cases, the Supreme Court repeatedly reaffirmed that the President's authority to impose martial law is constitutional and that it comes directly from the Militia Acts. As Part II concludes, even one of the two cases most commonly cited for the proposition that the President possesses broad, "inherent" emergency power ${ }^{15}$ more properly fits into this regime.

Finally, in Part III, the Note examines why academics have overlooked the importance of the Militia Acts. Several prominent scholars of presidential power in the mid-twentieth century, most notably Edward Corwin and Charles Fairman, examined the Militia Acts but failed to account fully for their import. ${ }^{16}$ But in contrast to Corwin and Fairman, who at least acknowledged the potential relevance of the Militia Acts, most contemporary scholars of emergency power have ignored these statutes and their important contribution to our understanding of the constitutional dynamic. ${ }^{17}$ Restoring the role of the Militia Acts to this debate is the central project of this Note.

For obvious reasons, emergency power has once again returned to the forefront of the American legal academy, as scholars attempt to flesh out the nature and extent of the government's authority during crises, terrorism related and otherwise. ${ }^{18}$ Though emergencies have always been a popular topic for constitutional scholars, it has been decades since the last significant wave of academic writing on the topic and sixty years since the most comprehensive works were written. Part III concludes that, because of small but significant misreadings by Corwin and his disciples, much has been forgotten about the constitutional sources of governmental crisis authority during the quiet years of this debate. It is unquestionably

15. In re Debs, 158 U.S. 564 (1895); Cunningham v. Neagle (In re Neagle), 135 U.S. 1 (1890).

16. The principal works on which this Note's analysis relies are EDWARD S. CORWIN, THE PRESIDENT: OFFICE AND POWERS, 1787-1948 (3d rev. ed. 1948), and CHARLES FAIRMAN, THE LAW OF MARTIAL RULE (2d ed. 1943). Corwin's work has since undergone two additional revisions, but this Note relies on the 1948 edition because his arguments on relevant points have not changed naterially in either of the subsequent editions.

17. The exception among modern academics is Daniel Farber, who openly acknowledges the Militia Acts in his discussion of Lincoln's actions during the Civil War. See, e.g., FARBER, supra note 3, at 162-63. But as Part III suggests, Farber makes many of Corwin's missteps in misreading the Prize Cases and thus fails to acknowledge the importance and centrality of the Militia Acts.

18. See, e.g., Symposium, Civil Liberties in a Time of Terror, 2003 WIS. L. REV. 253; Jules Lobel, The War on Terrorism and Civil Liberties, 63 U. PITT. L. REV. 767 (2002); sources cited supra note 8 ; cf. Oren Gross, Providing for the Unexpected: Constitutional Emergency Provisions, in 33 ISRAEL YeARBoOK ON HUMAN RightS 13 (Yoram Dinstein \& Fania Domb cds., 2004) (surveying various foreign emergency provisions). 
important, going forward, to remember the extent to which the Constitution gives Congress this important emergency power. But this Note concludes that it is equally important for Congress to delineate adequately the scope of the President's broad power to use the military in responding to emergencies, and to do so before, rather than after, the next crisis.

\section{The First Militia Clause AND THE Militia ACTS}

This Part introduces the Militia Acts by situating them in their proper context, beginning with the debates at the Philadelphia Convention over the scope and extent of domestic military crisis authority. After surveying the competing interests present at Philadelphia, the crux of this Part examines the background and language of the Militia Acts-enacted in 1792, 1795, 1807,1861 , and 1871 - which regulated the circumstances in which the President can use troops to respond to domestic crises. Taken together, this history suggests the extent to which these statutes manifested Congress's intent to use the First Militia Clause and Congress's other Article I, Section 8 powers as the major vehicles for bestowing significant emergency power upon the Executive. As this Part concludes, reading the statutes side by side yields significant conclusions about the nature of the delegation of power and the extent to which much of its exercise was left open to judicial interpretation and executive discretion.

\section{A. The Constitution and Emergency Power}

The Constitution as drafted unquestionably created military crisis authority but carefully policed its source and potential operation, largely in response to the fears of a powerful army that dominated the Philadelphia Convention. Although many local and state militias had played important roles in colonial America and during the Revolutionary War, ${ }^{19}$ it was commonly believed that a strong national army would pose a dangerous and potentially insurmountable threat to the autonomy and authority of the states within the fledgling Republic. ${ }^{20}$ Notwithstanding this tension, it became clear that, under the Articies of Confederation, the lack of

19. See Richard H. KoHn, EAgle and Sword: THE FEDERalists and the Creation of THE MILITARY EST ABLISHMENT IN AMERICA, 1783-1802, at 1-13 (1975).

20. ROBERT W. COAKLEY, THE ROLE OF FEDERAL MILITARY FORCES IN DOMESTIC DISORDERS, 1789-1878, at 3 (1988); see also FREDERICK T. WILSON, FEDERAL Aid IN DOMESTIC DISTURBANCES: $1787-1903$, S. DOC. NO. 57-209, at 16 (2d Sess. 1903). This Note owes a substantial debt to the efforts of Wilson and of Coakley, whose work served largely "to update Wilson." COAKLEY, supra, at vii; see also Clayton D. LAURIE \& RONALD H. COLE, The ROLE OF FEDERAL MILITARY FORCES IN DOMESTIC DISORDERS, 1877-1945 (1997). 
centralized federal control over the disparate armed bands had become untenable. As Alan Hirsch summarized,

Under the Articles, the states retained the power to train and equip the militias and to appoint most officers, whereas Congress could raise troops by requisitioning each state for its proportionate quota of men. There was no way for Congress to force state cooperation, and such cooperation was often not forthcoming. The framers of the Constitution were conscious of the inadequacy of the military system and sought to redress it. ${ }^{21}$

The central point of contention at Philadelphia over the militia was not the scope of the militia's authority, but who would be responsible for invoking it. ${ }^{22}$ Questions of federalism dominated, as the Framers debated "the extent of power the federal government and the states, respectively, would and should have over the militia." ${ }^{23}$ Most everyone at the Convention dreaded a powerful standing army, and nearly as many feared a central, dominant Chief Executive. The consensus thus clearly favored vesting the primary responsibility for responding to threats in the militias of the several states, though the federal government-through Congress, not the President-would exercise ultimate control. ${ }^{24}$

Yet, there was no articulated concern, either at Philadelphia or in any of the ratification debates, over the three broad circumstances in which the Clause gave Congress the authority to call forth the militia-executing the laws, suppressing insurrections, and repelling invasions. ${ }^{25}$ The Framers understood that there would be occasions requiring resort to extraordinary measures that they themselves could not fully delineate. The crucial issue was in which branch they would vest this critical discretion.

Finally, because of the fears of a standing army, the broad power the Framers conferred upon Congress did not explicitly include the power to use the regular army in internal emergencies. It wasn't that such power was

21. Alan Hirsch, The Militia Clauses of the Constitution and the National Guard, 56 U. CIN. L. REV. 919, 923 (1988) (citations omitted).

22. See COAKLEY, supra note 20 , at 7 (" $[\mathrm{T}]$ he right of the federal government ... to use military force in domestic disorders was not a subject of extended debate in the Constitutional Convention. With few exceptions the convention delegates accepted the premise that the new national government must possess a coercive power that the Confederation had lacked ....").

23. Hirsch, supra note 21 , at 924 . For a summary of the debates, see Patrick Todd Mullins, Note, The Militia Clauses, the National Guard, and Federalism: A Constitutional Tug of War, 57 Geo. WASH. L. REV. 328, 330-32 (1988). See also H. RICHARD UVILlER \& WILLIAM G. MERKEL, THE Militia AND THE RIGHT TO ARMS, OR, HOW THE SECOND AMENDMENT FELL SILENT 72-78 (2002).

24. See S. DOC. NO. 57-209, at 16; see also COAKLEY, supra note 20, at 12 ("[T]he military clauses of the Constitution were hammered out in a debate in which the opposition to peacetime standing armies and to federal control over the militia asserted itself strongly.").

25. See Hirsch, supra note 21, at 926. 
left to the President; rather, "no power to use regular forces in domestic disorders was explicitly granted to either the president or Congress," which was "testimony to the fear of standing armies that pervaded the meeting." The Convention voted down an amendment by George Mason that would have added a preface to the First Militia Clause expressing the fear of standing armies but permitting their use in certain situations. ${ }^{27}$ As Justice Jackson would later note, the First Militia Clause's "limitation on the command power, written at a time when the militia rather than a standing army was contemplated as the military weapon of the Republic, underscores the Constitution's policy that Congress, not the Executive, should control utilization of the war power as an instrument of domestic policy." ${ }^{28}$ At least initially, the consensus was that the President was to have a role in exercising emergency power, but primarily as "Commander in Chief ... of the Militia of the several States, when called into the actual Service of the United States."29

In sum, one of the Framers' dominant concerns was the federal government's ability to defend itself (and, as manifested in the Guarantee Clause, the several states ${ }^{30}$ ). In addition to the power to declare war on foreign enemies (which the Constitution also vested in Congress, but which, as has been well documented, has eroded somewhat over time ${ }^{31}$ ), the Constitution, via the First Militia Clause, also gave the government the power to use the militia to defend itself from threats both foreign and domestic. As Justice Jackson would later write, the Framers "knew what emergencies were, knew the pressures they engender for authoritative action, knew, too, how they afford a ready pretext for usurpation. We may also suspect that they suspected that emergency powers would tend to kindle emergencies." 32 Given this suspicion, the issue confronting early Congresses was how to delegate the broad authority conferred on Congress by the First Militia Clause. ${ }^{33}$

26. COAKLEY, supra note 20 , at 14 (emphasis added).

27. See id. at 14-19.

28. Youngstown Sheet \& Tube Co. v. Sawyer (Steel Seizure), 343 U.S. 579, 644 (1952) (Jackson, J., concurring); see also THE FEDERALIST No. 29, at 185-87 (Alexander Hamilton) (Clinton Rossiter ed., 1961) (suggesting that the militia, and not the regulars, were the more reliable force in an emergency, and therefore the more appropriate body to exercise emergency power).

29. U.S. CONST. art. II, $\S 2$, cl. 1.

30. Id. art. IV, $\S 4$.

31. See, e.g., JOHN HART ELy, WAR AND RESPONSIBILITY: CONSTITUTIONAL LESSONS OF VIETNAM AND ITS AFTERMATH (1993).

32. Steel Seizure, 343 U.S. at 650 (Jackson, J., concurring).

33. See UVILLER \& MERKEL, supra note 23, at 77 (suggesting that the Clause was meant to be broadly delegated-the President would not have to wait around "like the early Stuarts" for Congress's approval to respond to military crises). 


\section{B. "Calling Forth" the State Militias: The 1792 and 1795 Militia Acts}

On May 2, 1792, the Second Congress temporarily delegated its authority under the First Militia Clause by passing a statute "to provide for calling forth the Militia to execute the laws of the Union, suppress insurrections and repel invasions." ${ }^{34}$ Recall from above that the First Militia Clause empowered Congress to provide for the calling forth of the militia in three circumstances: to execute the laws of the union, to suppress insurrections, and to repel invasions. ${ }^{35}$ In final form, section 1 of the 1792 Calling Forth Act, which met with very little debate, ${ }^{36}$ covered the latter two circumstances, providing

[t]hat whenever the United States shall be invaded, or be in imminent danger of invasion from any foreign nation or Indian tribe, it shall be lawful for the President of the United States, to call forth such number of the militia of the state or states most convenient to the place of danger or scene of action, as he may judge necessary to repel such invasion, and to issue his orders for that purpose, to such officer or officers of the militia as he shall think proper; and in case of an insurrection in any state, against the government thereof, it shall be lawful for the President of the United States, on the application of the legislature of such state, or of the executive (when the legislature cannot be convened) to call forth such number of the militia of any other state or states, as may be applied for, or as he may judge sufficient to suppress such insurrection. ${ }^{37}$

Section 2, which dealt with the first circumstance under which Congress was constitutionally entitled to provide for the calling forth of the militia, met with much firmer resistance. ${ }^{38}$ After long exchanges on the House floor centering on the types of laws the President could call forth the militia to execute, various amendments were added, including one requiring

34. Calling Forth Act of 1792, ch. 28, I Stat. 264, 264 (repealed 1795). Congress had twice previously given President Washington specific authority to call out the militia to protect settlers on the frontier. See Act of Apr. 30, 1790, ch. 10, $\$ 16,1$ Stat. 119, 121 (repealed 1795); Act of Sept. 29, 1789, ch. 25, § 5, 1 Stat. 95, 96 (expired 1790). For a discussion of the First Congress and the problems faced on the frontiers, see DAVID P. CURRIE, THE CONSTITUTION IN CONGRESS: THE FEDERALIST PERIOD, 1789-1801, at 85-87 (1997).

35. U.S. CONST. art. I, $\$ 8$, cl. 15 .

36. See David E. Engdahl, Soldiers, Riots, and Revolution: The Law and History of Military Troops in Civil Disorders, 57 lowA L. REV. 1, 44 (1971).

37. Calling Forth Act of $1792 \S 1,1$ Stat. at 264.

38. See Engdahl, supra note 36, at 44 ("From the record of the House debate, it appears that the Representatives were not troubled over the use of the militia in circumstances so grave as invasion or outright insurrection; but they were deeply concerned over the prospect of troops being used in common civilian situations 'to execute the laws of the Union." ). 
judicial intervention and a second mandating that the President first order the insurgents to disperse. ${ }^{39}$ As the final text provided,

[W]henever the laws of the United States shall be opposed, or the execution thereof obstructed, in any state, by combinations too powerful to be suppressed by the ordinary course of judicial proceedings, or by the powers vested in the marshals by this act, the same being notified to the President of the United States, by an associate justice or the district judge, it shall be lawful for the President of the United States to call forth the militia of such state to suppress such combinations, and to cause the laws to be duly executed. And if the militia of a state, where such combinations may happen, shall refuse, or be insufficient to suppress the same, it shall be lawful for the President, if the legislature of the United States be not in session, to call forth and employ such numbers of the militia of any other state or states most convenient thereto, as may be necessary, and the use of militia, so to be called forth, may be continued, if necessary, until the expiration of thirty days after the commencement of the ensuing session. ${ }^{40}$

In contrast to section 1, section 2 allowed the use of militia from another state only when Congress was out of session-were Congress around, presumably, the President would have to go to the legislature for a more specific authorization.

Finally, after providing guidelines for the governance of the militia once called forth, the Second Congress made its delegation temporary, providing " $[\mathrm{t}]$ hat this act shall continue and be in force, for and during the term of two years, and from thence to the end of the next session of Congress thereafter, and no longer." ${ }^{.41}$ The Act was meant to be a threeyear-long experiment, but a broad one at that. ${ }^{42}$

Two years after the enactment of the Calling Forth Act, President Washington relied exclusively on the Act in suppressing the Whiskey Rebellion in western Pennsylvania. Though the Act had been invoked before, ${ }^{43}$ the Whiskey Rebellion was " $[t]$ he great precedent for the use of federal military force in internal disturbances," ${ }^{44}$ and it illustrates the extent

39. See id. at 45-47; see also 3 ANNALS OF CONG. 574-79 (1792). The dispersal proclamation requirement was included in section 3 of the Act, and was ultimately required whenever the President invoked his authority under any provision of the Act. $\S 3,1$ Stat. at 264.

40. $\S 2,1$ Stat. at 264 .

41. Id. $\S 10,1$ Stat. at 265 .

42. See CURRIE, supra note 34, at 162; see also Jay S. Bybee, Insuring Domestic Tranquility: Lopez, Federalization of Crime, and the Forgotten Role of the Domestic Violence Clause, 66 GEO. WASH. L. REV. 1, 41-43 (1997).

43. COAKLEY, supra note 20 , at 24-28 (describing the use of the Act during the Genet affair).

44. Id. at 24. 
to which early practice assumed that the Act governed the President's authority to respond to an internal crisis. In response to the uprising on Pennsylvania's frontier, ${ }^{45}$ Washington sought and received certification from Supreme Court Justice James Wilson that circumstances necessitated calling forth the militia. ${ }^{46} \mathrm{He}$ then issued a proclamation commanding the insurgents to disperse, and when his call went unheeded, he assembled militiamen from four states-Pennsylvania, New Jersey, Virginia, and Maryland-who eventually quelled the threat. ${ }^{47}$

Toward the end of the uprising, the Third Congress, in the first legislative action of its second session, passed a statute specifically reauthorizing the calling forth of the militia to keep the peace for an additional three months and, if necessary, until thirty days after the beginning of the next session of Congress. ${ }^{48}$ The reauthorization statute was necessary because section 2 of the 1792 Act explicitly barred the President from using the militias of other states for more than thirty days once Congress was back in session, which it had not been since the beginning of the insurgency. But the specific details are largely insignificant; what matters here is the extent to which everyone-the President, the Supreme Court (through Justice Wilson), and Congress-closely adhered to the explicit dictates of the 1792 Calling Forth Act. At no point did anyone suggest that the Executive possessed any separate authority to deal with the rebels. That Washington and his contemporaries used the Calling Forth Act, and not any other source of power, as the authority for suppressing the Whiskey Rebellion is as significant a statement of early understanding as exists.

Yet, as much as the Calling Forth Act worked as intended during the Whiskey Rebellion, Washington's experience dealing with the rebellion also highlighted the flaws that the case-by-case regime necessarily created, flaws that he implored the Third Congress to rectify. ${ }^{49}$ Despite Washington's suggestions, Congress did not seriously consider his suggested reforms to the militia system, though it gave its imprimatur to

45. For what remains today the authoritative history of the Whiskey Rebellion, see LELAND D. BALDWIN, WHISKEY REBELS: THE STORY OF A FRONTIER UPRISING (1939).

46. Why Washington used section 2 instead of section 1 -i.e., why he did not treat the uprising as an "insurrection," but rather as "combinations too powerful to be suppressed by the ordinary course of judicial proceedings"-is unclear. It may have been dubious whether the actions of the Whiskey Rebellion farmers truly rose to the level of insurrection.

47. See Frederick T. WILSON, Federal AID IN DOMESTIC DisturbanCES: 1787-1903, S. DOC. No. 57-209, at 33-42 (2d Sess. 1903); COAKLEY, supra note 20, at 36-42. For details of the military expedition itself, see $i d$. at 43-68.

48. See Act of Nov. 29, 1794, ch. 1, 1 Stat. 403 (expired 1795).

49. George Washington, Sixth Annual Address to Congress (Nov. 19, 1794), in 34 THE WRITINGS OF GEORGE WASHINGTON FROM THE ORIGINAL MANUSCRIPT SOURCES, 1745-1799, at 28, 33-35 (John C. Fitzpatrick ed., 1940). 
his conduct by reenacting the Calling Forth Act on a permanent basis in 1795 with various revisions to enhance the President's powers under the Act. Indeed,

[b]y his actions in the Whiskey Rebellion, Washington had apparently dissipated the fears expressed in 1792 that these powers "could not with safety be entrusted to the President of the United States." The Whiskey Rebellion thus resulted in the establishment of both a permanent law and a precedent for all future use of federal military force in domestic disorders. ${ }^{50}$

In reenacting the Calling Forth Act, the Third Congress replaced the original statute with the 1795 Militia Act, which removed-or heavily diluted-several of the major checks on the President's authority under section 2, though it left section 1 of the 1792 Act entirely intact. The 1795 Act changed the nature of the section 2 delegation in three critical ways. First, the Act removed the requirement of an antecedent court order-which had been added as a necessary amendment in 1792 - leaving the President as the sole arbiter of when circumstances necessitated the calling forth of the militia. ${ }^{51}$ Second, the 1795 Act removed the 1792 Act's requirement that militiamen from other states could be used only when Congress was not in session, ${ }^{52}$ despite the fears at Philadelphia that militiamen from New Hampshire might be sent to quell a disturbance in Georgia, and vice versa. ${ }^{53}$ Third, the 1795 Act kept the dispersal proclamation requirement but removed the requirement from the 1792 Act that such a proclamation be issued "previous thereto," i.e., before calling out the militia. ${ }^{54} \mathrm{~A}$ fair reading of the 1795 Act suggests that all Congress sought to require was a contemporaneous proclamation-notice to the rebels that the troops were on their way. Per the amended section 2 ,

[W]henever the laws of the United States shall be opposed, or the execution thereof obstructed, in any state, by combinations too powerful to be suppressed by the ordinary course of judicial proceedings, or by the powers vested in the marshals by this act, it

50. COAKLEY, supra note 20 , at $67-68$ (footnote omitted).

51. To see this difference, compare the Militia Act of 1795 , ch. 36, $\S 2,1$ Stat. 424, 424 (repealed 1861), with the Calling Forth Act of 1792, ch. 28, § 2, 1 Stat. 264, 264 (repealed 1795). See also CORWIN, supra note 16, at 161 (summarizing the differences between the 1792 and 1795 statutes); cf. CURRIE, supra note 34, at 161-62 \& n.228 (noting that the 1795 statute omitted two requirements in the 1792 statute and watered down a third).

52. Compare Militia Act of $1795 \S 2,1$ Stat. at 424, with Calling Forth Act of 1792 \& 2, 1 Stat. at 264.

53. See THE FEDERALIST No. 29, supra note 28 , at 186-87 (Alexander Hamilton).

54. Compare Militia Act of $1795 \S 3,1$ Stat. at 424, with Calling Forth Act of $1792 \S 3,1$ Stat. at 264 . 
shall be lawful for the President of the United States, to call forth the militia of such state, or of any other state or states, as may be necessary to suppress such combinations, and to cause the laws to be duly executed; and the use of militia so to be called forth may be continued, if necessary, until the expiration of thirty days after the commencement of the then next session of Congress. ${ }^{55}$

Thus, whereas section 2 of the 1792 Act envisioned a multistage process (as during the Whiskey Rebellion) in which the President first had to receive judicial acknowledgment of a crisis requiring the militia, then could issue a proclamation ordering the insurgents to disperse, and then could call out the militia only after such a proclamation had gone unheeded, section 2 of the 1795 Act authorized the President to act decisively, expeditiously, and, of most significance, unilaterally. ${ }^{56}$ Whereas the Second Congress had intended the delegation of such broad authority to sunset after three years and had required the intervention of a federal judge, the Third Congress made the delegation permanent and expanded the President's authority in the three critical areas discussed above-removing the requirement of an antecedent court order and the bar on the use of out-ofstate militiamen and changing the timing of the dispersal proclamation requirement. ${ }^{57}$ The 1792 and 1795 Acts thus clearly indicate the early thinking behind presidential power in military emergencies-the power was unquestionably Congress's to delegate.

\section{C. "Calling Forth" the Federal Army: The 1807 and 1861 Acts}

At first, the 1792 and 1795 Militia Acts were broad delegations of authority with a narrow application-the Acts authorized the President to call forth only the state militias, many, if not most, of which were in

55. Militia Act of $1795 \S 2,1$ Stat. at 424 . The time limit-capping the power "thirty days after the commencement of the then next session of Congress"-suggests that Congress very much had in mind the President's authority to act when Congress was not in session, both in 1792 and 1795. See, e.g., supra text accompanying note 48 (describing Congress's necessary reauthorization of the use of the militia to put down the Whiskey Rebellion). The thirty-day limit, extended to sixty days in 1861 , see infra text accompanying notes $69-73$, required Congress to weigh in when it was in session, at least when the militia was called forth other than to suppress insurrections or repel invasions.

56. See CORWIN, supra note 16 , at 161.

57. Perhaps by accident, the 1795 Act actually reined in presidential authority in one area, however. Under the 1792 Act, only orders requiring militiamen to serve in other states expired after thirty days absent congressional reauthorization. See Calling Forth Act of $1792 \S 2$, I Stat. at 264. In removing the distinction between the use of the home-state militia and that of other states, the 1795 Act thus expanded the time limit to also include orders calling forth the militia of the state in which the obstructions had taken place. See Militia Act of $1795 \S 2,1$ Stat. at 424. I thank Sydney Foster for raising this important point (and countless others). 
significant disarray at the Founding. ${ }^{58}$ President Adams used the 1795 Act to threaten use of the militia in response to Fries's Rebellion in early $1799 .^{59}$ On March 2 of that same year, Congress temporarily authorized the President to use the federal army whenever the 1795 Act allowed him to call out the state militias. ${ }^{60}$ Eight years later, prompted somewhat by discrete events in 1806 and 1807-border incursions in the Southwest by Spanish troops ${ }^{61}$ and the infamous Burr conspiracy ${ }^{62}$ - the Ninth Congress permanently supplemented the 1795 Act with a statute comprising a single sentence:

[I]n all cases of insurrection, or obstruction to the laws, either of the United States, or of any individual state or territory, where it is lawful for the President of the United States to call forth the militia for the purpose of suppressing such insurrection, or of causing the laws to be duly executed, it shall be lawful for him to employ, for the same purposes, such part of the land or naval force of the United States, as shall be judged necessary, having first observed all the pre-requisites of the law in that respect. ${ }^{63}$

The legislative history behind the Insurrection Act is nonexistent, ${ }^{64}$ which is troubling because the Act clearly omitted invasion from those circumstances where the federal regulars could be used. But for the open

58. See generally KOHN, supra note 19 (providing an overview of the decline of the state militia systems in the early Republic - and the role of the Militia Acts in hastening this decline).

59. See FrFderick T. WILSON, FEDERAL AID IN DOMESTIC DisturbanCES: 1787-1903, S. DOC. NO. 57-209, at 42-45 (2d Sess. 1903); see also COAKLEY, supra note 20, at 69-77. There is not room within these pages to fully document every instance in which the Militia Acts were invoked in the early Republic, but as Wilson and Coakley demonstrate, it was commonplace to rely on this statutory framework whenever resort to domestic military authority was necessary.

60. See Act of Mar. 2, 1799, ch. 31, § 7, 1 Stat. 725, 726 (repealed 1802). The first statute allowing the President to call forth a joint contingent of the militia and the "land or naval forces of the United States" was the Neutrality Act of 1794, ch. 50, $\$ \$ 7-8,1$ Stat. 381,384 (current version at 18 U.S.C. $\S 960(2000)$ ). See COAKLEY, supra note 20 , at $346-47$ ("It was really this law that led directly to another law passed in 1807 permitting the president to use the regular military forces for the same purposes that the law of 1795 permitted him to use the militia.").

61. See S. DOC. No. 57-209, at 45-46; DAVID P. CURRIE, The CONSTITUTION IN CONGRESS: THE JEFFERSONIANS, $1801-1829$, at $8 \mathrm{n} .29$ (2001).

62. For the extent to which the 1807 Act was motivated by the actions of Burr and his cohorts, see George M. Dennison, Martial Law: The Development of a Theory of Emergency Powers, 1776-1861, 18 AM. J. LegAL HIST. 52, 56-58 (1974). See also COAKLEY, supra note 20, at 83 ("In terms of the history of the use of federal military force in domestic disorders, the most important result of the Burr conspiracy was the passage of a law, signed by Jefferson on 8 March 1807 , authorizing the use of regulars as well as militia in these affairs.").

63. Insurrection Act of 1807 , ch. 39, 2 Stat. 443, 443 (current version at 10 U.S.C. $\$ \S 331$ 335 (2000)); see also Dennison, supra note 62, at 58 ("This legislation confirmed the President's unilateral action during the Burr scare, but left intact the presumptions conceming the subordination of military to civilian authority.").

64. See COAKLEY, supra note 20, at $83 \mathrm{n} .46$ ("There is no record of any debate in Congress."). The Act was one of many passed on the last day of the Ninth Congress. 
hostility on the part of the Framers toward the use of a standing army in any circumstance, one might easily infer that Congress omitted invasions from the 1807 Act because it believed that the President inherently possessed the power to use federal troops to repel invaders. Yet this understanding raises the difficult question of why Congress would differentiate between repelling invaders and suppressing insurrections in 1807 , especially since it did not so differentiate in $1799 .{ }^{65}$

An alternate supposition might be that concerns over the standing army led Congress in 1807 to extend the calling-forth power only to those cases in which the state militias might be compromised-to insurrections within a state or obstruction of the laws therein-and to leave to the state militias the initial responsibility of dealing with invaders, with other state militias available to help should they be so summoned by the President under the auspices of section 1 of the 1795 Act. The critical distinction between the various cases was that invasions were the only instance in which the state militia itself might not be one of the actors against which force was needed.

But in addition to the lack of legislative history, there is also no academic discussion of this subtle change in wording between the 1795 and 1807 Acts. In the absence of additional discourse, neither of these arguments can carry their own weight. This leaves the omission of invasion from the 1807 Act a rather uncomfortable mystery. It certainly is not obvious that Congress omitted invasion out of respect for the President's inherent constitutional authority, in part because Congress did not make a similar omission in the 1799 Act. Regardless, there can be little doubt that Congress clearly meant to expand the calling-forth power to the regular army in the other two contexts, including on those occasions governed by section 2 of the 1795 Act.

One other important result of the 1807 Act was Congress's departure from the First Militia Clause as the exclusive source of its authority to regulate the President's emergency military power, because the Clause said nothing about the use of federal troops. ${ }^{66}$ Instead, the 1807 Act is better viewed as an amalgamation of Congress's calling-forth power with its other Article I, Section 8 war powers. As Coakley concludes, "The development of law on the two types of action [by the militia or by federal regulars] followed a roughly similar course, although the laws were based upon different constitutional clauses." ${ }^{27}$ In this fashion, the Insurrection Act started a trend that has continued to today-a trend in which Congress drew

65. See supra note 60 and accompanying text.

66. See U.S. CONST. art. I, $\S 8, \mathrm{cl} .15$.

67. COAKLEY, supra note 20 , at 347. 
on all of its constitutional authority, and not just the First Militia Clause, to legislate presidential emergency power. ${ }^{68}$

The Militia Acts regime remained entirely untouched for the next halfcentury until, on the eve of the Civil War, Congress once again tinkered with the language of the 1795 Act, scrapping section 2 in favor of a provision more amenable to the federalization of the militia in the looming war against the Confederacy. Most importantly, section 1 of the 1861 Act, which replaced section 2 of the 1795 Act (the provision that had dealt with calling forth the militia to execute the laws of the union), authorized the President to call forth the militia or the federal armed forces

whenever, by reason of unlawful obstructions, combinations, or assemblages of persons, or rebellion against the authority of the Government of the United States, it shall become impracticable, in the judgment of the President of the United States, to enforce, by the ordinary course of judicial proceedings, the laws of the United States within any State or Territory [thereof] ... .69

The shift from the authority delegated by the 1795 Act to that provided by the 1861 Act was subtle but crucial. The 1861 Act expanded the President's power to use the militia to "execute the laws" to allow him to call out the militia (and the federal armed forces) until sixty days after the beginning of the then-next legislative session, unless Congress were to intervene with a veto-proof resolution, ${ }^{70}$ whenever, in his judgment, it became "impracticable... to enforce... the laws of the United States within any State or Territory." 71

Though cases before the Civil War had already endorsed widespread presidential discretion under the Militia Acts, as discussed in more detail in Part II, the 1861 Act crystallized and codified the general principles behind those decisions, particularly Luther v. Borden. ${ }^{72}$ Specifically, the 1861 Act

68. Here, it is impossible to overstate the signal importance of the Insurrection Act to this Note's thesis. By extending the President's calling-forth power to the federal armed forces, the Ninth Congress vitiated any arguments that the Constitution, through the First Militia Clause and other provisions, granted Congress limited authority over only state militias, to be invoked in highly specific situations. When the Supreme Court affirmed the constitutional structure as implemented by the 1795 and 1807 Acts in the cases discussed in Part II, it was thus far more significant that it was affirming the Insurrection Act, for the later statute was the less obviously constitutional of the crucial pair.

69. Suppression of the Rebellion Act of 1861, ch. 25, $\S 1,12$ Stat. 281, 281 (current version at 10 U.S.C. $\S 332(2000)$ ). The 1861 Act also replaced sections 3 and 4 of the 1795 Act-the proclamation requirement and a provision subjecting the militias, once called forth, to the same rules governing the conduct of the regulars. Section 1 of the 1795 Act, which governed the calling forth of the militia to repel invaders or suppress insurrections, was left wholly intact.

70. Id. $\S 3,12$ Stat. at 282 .

71. Id. $\S 1,12$ Stat. at 281 .

72. 48 U.S. (7 How.) 1 (1849). 
included three critical shifts from the existing regime. First, the $1861 \mathrm{Act}$ doubled the time period during which the President was authorized to call forth the militia. Second, the Act expressly committed to the President's sole discretion the determination that it was "impracticable" to execute the laws. Last, the Act also added "rebellion against the authority of the Government of the United States" to the list of instances under which the power to use the militia to "execute the iaws" could be invoked..$^{73}$ Though this provision was clearly intended to apply to the Confederacy, it would also be relied upon ten years later for the authority to use military force to respond to the Ku Klux Klan. In all, to whatever extent the 1795 Act had removed or changed three important checks on the President's emergency authority under the $1792 \mathrm{Act}^{74}$ the 1861 Act heavily diluted the major checks that remained. ${ }^{75}$

\section{Martial Law, Habeas Corpus, and the Ku Klux Klan}

The 1861 Act represented the third major revision to the Militia Act regime, but the statutes have remained almost entirely unchanged in the 143 years since. ${ }^{76}$ The one exception, the Ku Klux Klan (Civil Rights) Act of 1871, helps underscore the importance of this Part's analysis of the specific statutes to the Note's underlying thesis. Though the 1871 Act was specifically targeted at the Klan, its delegation of emergency powers to the President was broader, for it allowed the calling forth of the militia or the regular army, or the resort to "other means," to enforce the civil rights conferred by the Act, the earlier enforcement acts, and the Constitution more generally—specifically, the Fourteenth Amendment. ${ }^{77}$

73. $\S 1,12$ Stat. at 281 . The "rebellion" language ensured, whether deliberately or not, that there would be no constitutional questions as to the propriety of suspending habeas corpus if the President were to impose martial law under section l of the 1861 Act, since the Suspension Clause allows suspensions of the writ only "when in Cases of Rebellion or Invasion the public Safety may require it." U.S. CONST. art. I, $\S 9, \mathrm{cl}$. 2 . No such language was required for section 1 of the 1795 Act, which remained intact, given that it applied, on its terms, only to suppressing insurrections and repelling invaders.

74. See supra text accompanying notes 51-54.

75. See COAKLEY, supra note 20 , at 228 (noting that the 1861 Act "vastly strengthened the president's authority to use both militia and regulars to suppress insurrections and execute the laws of the Union").

76. The regime underwent some revision when Congress passed the Dick Act in 1903, which replaced the Uniform Militia Act of 1792 as the federal regulatory statute for the militias. See Dick Act, ch. 196, § 25, 32 Stat. 775, 780 (1903); see also Militia Reform Act of 1908, ch. 204, 35 Stat. 399 (formerly codified at 32 U.S.C. $\$ 81$ a (1952)). Otherwise, nearly all of the language of the Suppression of the Rebellion Act can be found in the U.S. Code today. Compare Suppression of the Rebellion Act of $1861 \S \S 1-3,12$ Stat. at 281-82, with 10 U.S.C. $\$ \S 331-335$ (2000).

77. Ku Klux Klan (Civil Rights) Act of 1871, ch. 22, § 3, 17 Stat. 13, 14 (current version at 10 U.S.C. $\S 333$ (2000)); see also Force Act, ch. 114, § 13, 16 Stat. 140, 143 (1870) (formerly 
Section 4, by far the most powerful provision of the Act, even authorized the suspension of habeas corpus to put down any rebellious activity that threatened the enforcement provisions of the statute, though it made such actions contingent upon the dispersal proclamation still required by the Militia Acts. ${ }^{78}$ That provision, though it would expire at the end of the next congressional session, underscores the extent to which martial law was understood to come from the 1795 and 1807 Acts. This proposition follows from the language of section 4 , which specifically referred to the Militia Acts as part of the process the President must follow in order to suspend the writ, ${ }^{79}$ even though there was no relationship between habeas and the Militia Acts-except under the theory that suspension was coincident to the imposition of martial law. ${ }^{80}$

The 1871 Act highlights the evolution and drift of this broad area of emergency power during the first hundred years of the Republic away from the original understanding that the use of the military would be limited to state militias - and then only in cases where troops were necessary to suppress insurrections, to repel invasions, or to overcome "combinations too powerful to be suppressed by the ordinary course of judicial proceedings." 81

By 1871 , the President had unfettered statutory discretion to employ the militias or the (now-powerful) federal army when certain conditions were met. To that end, the 1871 Act textually committed to a conclusion the courts had long since reached - that the imposition of martial law and the suspension of habeas corpus were necessarily concomitant to this power under certain statutorily prescribed circumstances. Although the Posse Comitatus Act, enacted in 1878, created clear limits on the domestic use of the federal military for crisis management (largely to respond to Reconstruction-era excesses), ${ }^{82}$ the Militia Acts were among the few statutory and constitutional provisions exempted from its coverage. ${ }^{83}$

codified at 42 U.S.C. $\S 1993$ (1952) and repealed 1957) (authorizing the use of the militia or the regulars to enforce aspects of the Act). For an excellent contemporary overview of the Ku Klux Klan Act's background and impact, see James Forman, Jr., Juries and Race in the Nineteenth Century, 113 YALE L.J. 895, 920-26 (2004). Though many of the provisions of the various enforcement and force acts were struck down by the Supreme Court in United States v. Harris, 106 U.S. 629 (1883), the Court left section 3 of the Ku Klux Klan Act intact (section 4 had long since expired).

78. Ku Klux Klan (Civil Rights) Act of $1871 \S 4,17$ Stat. at 14-15 (expired 1873).

79. See id.

80. See infra text accompanying notes 116-120.

81. Calling Forth Act of 1792, ch. 28, \& 2, 1 Stat. 264, 264 (repealed 1795).

82. Posse Comitatus Act of 1878 , ch. $263, \S 15,20$ Stat. 145,152 (codified as amended at 18 U.S.C. $\$ 1385(2000)$ ).

83. See COAKLEY, supra note 20 , at 345 . 
But what is at least as telling about the evolution of the Militia Acts is the consistent movement away from specific checks on presidential authority under the regime, whether that movement was accomplished by Congress or, as Part II will demonstrate in more detail, by the courts. By the end of the nineteenth century, the Militia Acts had become an untethered broadsword-a body of executive emergency power that probably included, under certain circumstances, the authority to impose martial law and, the necessary byproduct, to suspend habeas corpus. Absent from the framework were any clear triggers creating distinctions between different degrees of authority under the Acts, even though common sense (and, as Part II suggests, case law) might otherwise demand that circumstances necessitating the calling forth of the militia do not always merit such extraordinary measures as martial law and the suspension of habeas.

Indeed, the gaps were left to be filled by presidential discretion that, as the courts would hold, was largely unreviewable. Though the history of the Militia Acts underscores the extent to which this structural relationship was what both the Framers and early Congresses intended, courts interpreting the Militia Acts regime only broadened executive authority under the Acts and seldom suggested limits. Part I demonstrates that one important actorCongress-viewed itself, and not the President, as the key source of emergency power. Over time, however, Congress gave away so much of its power that, except for the language of the decisions discussed in Part II, it might have been easy for commentators to overlook the source of such authority.

\section{The Militia ACTS, THE COURTS, AND EMERGENCIES}

This Part turns to the evolution of emergency power in nineteenthcentury U.S. courts. Before moving into the relationship between the Militia Acts and the courts, however, it bears emphasizing that the Supreme Court has mentioned the First Militia Clause itself on only a handful of occasions, ${ }^{84}$ and has interpreted it just twice-in 1918 in the Selective Draft Law Cases $^{85}$ and in 1990 in Perpich v. Department of Defense. ${ }^{86}$ With one

84. Clinton Rossiter, in his classic 1951 study of the relationship between the Supreme Court and the Commander in Chief, highlights only a handful of cases as containing useful discussions of the Clause, see ClinTON ROSSITER, THE SUPREME COURT AND THE COMMANDER IN CHIEF 14-15 \& n.4 (Richard Longaker ed., expanded ed. 1976), and only one significant interpretive decision-Perpich v. Department of Defense, 496 U.S. 334 (1990)-has been rendered since.

85. 245 U.S. 366 (1918). The Selective Draft Law Cases Court was faced with the question of whether the First Militia Clause, by limiting the circumstances in which Congress could provide for calling forth the state militias, served as a limit on Congress's incorporation of state militias into the federal military as part of its more general power to raise armies. Chief Justice White, writing for a unanimous Court, held that the Clause was not such a restriction, but was instead an additional grant of power to the legislature. See id. at 384 . 
exception, ${ }^{87}$ none of the readings of the Clause in either case bears on this Note in any significant fashion. Thus, our contemporary understanding must be guided instead by courts' interpretations of the statutes most directly implementing the Clause, to which this Note now turns. Section A of this Part discusses the importance of two early landmark cases, Martin $v$. Mott ${ }^{88}$ and Luther v. Borden, ${ }^{89}$ both of which read the Militia Acts as broad constitutional delegations of emergency power from Congress to the President-and as the source of the President's authority to impose martial law. Luther, still today one of the Court's most significant emergencypower decisions, squarely holds that the President's authority to impose martial law, such as it is, comes from the Militia Acts, though the Court struggled with defining the boundaries of such power.

Section B moves on to a broader discussion of emergency power during the Civil War, highlighted by the Supreme Court's decision in the Prize Cases, in which the Court sustained President Lincoln's imposition of a blockade by reference to the Militia Acts. ${ }^{90}$ Faced with the gravest national security crisis in the nation's history, the Court deferred to Congress. Finally, Section $\mathrm{C}$ concludes with a discussion of the two cases argued to espouse the so-called "inherent presidential power" theory and explains why at least one of them belongs more properly within the Militia Acts regime. In all, the evolution of emergency power in the courts closely tracked the evolution of the Militia Acts. Though courts finally began placing limits on executive power under the Militia Acts regime by the midtwentieth century, they continually upheld the statutes as a broad source of executive authority during internal emergencies.

\section{A. Martial Law in the Early Republic: Mott and Luther}

The President's discretion and the full scope of his authority under the Militia Acts regime had already been before the Supreme Court three times

86. 496 U.S. 334. Perpich sustained the President's authority to send National Guard members abroad for training without satisfying the preconditions of the First Militia Clause. As Justice Stevens wrote for a unanimous Court, the American dual-enlistment system presupposes that, once ordered to active federal duty, militia members become federal troops, and the provisions of the Militia Clauses no longer apply. See id. at 350 ("The congressional power to call forth the militia may in appropriate cases supplement its broader power to raise armies and provide for the common defense and general welfare, but it does not limit those powers.").

87. The exception is Perpich's reading of the power to call forth the militia in tandem with the power to raise armies and provide for the common defense, through which the Court implicitly suggested that authority under the Militia Acts regime was not necessarily limited to the First Militia Clause itself. This argument, however, necessarily followed from the text and history of the 1807 Insurrection Act. See supra note 68 and accompanying text.

88. 25 U.S. (12 Wheat.) 19 (1827).

89. 48 U.S. (7 How.) 1 (1849).

90. 67 U.S. (2 Black) 635 (1863). 
by 1861 . Though the first instance saw little in the way of serious discussion, ${ }^{91}$ the latter two cases-Mott and Luther-each embraced broad readings of Congress's authority under the First Militia Clause, the constitutionality of the 1795 Militia Act, and, as such, the President's authority and discretion to impose martial law (and, by implication, his power more generally during emergencies). The importance of Mott and Luther as the fountainhead precedents of American emergency power law is beyond question, ${ }^{92}$ so their reliance on the Militia Acts cannot be underscored enough.

At issue in Mott was whether a citizen could be court-martialed for his failure to join the New York militia when the President called it out during the War of 1812. Justice Story, writing for the Court, emphatically rejected the argument that the President lacked the authority to so mandate the service of citizens in their state militias, holding that such authority came from the 1795 Militia Act. ${ }^{93}$

Justice Story next turned to the issue of who was best suited to determine whether circumstances justified calling forth the military. A number of states had expressed serious skepticism (some bordering on outright nullification $)^{94}$ toward President Madison's authority to call out state troops, but the Mott Court decisively sided with the Executive. ${ }^{95}$ According to the Mott Court, the President's authority to determine whether a crisis had arisen necessitating the calling forth of the troops was unequivocally broad in its scope and unreviewable in its application:

If we look at the language of the act of 1795 , every conclusion drawn from the nature of the power itself, is strongly fortified...

91. See Houston v. Moore, 18 U.S. (5 Wheat.) 1 (1820).

92. See, e.g., Dennison, supra note 62, at 76.

93. In Justice Story's words, "It has not been denied here, that the act of 1795 is within the constitutional authority of Congress, or that Congress may not lawfully provide for cases of imminent danger of invasion, as well as for cases where an invasion has actually taken place." Mott, 25 U.S. (12 Wheat.) at 29. Story also suggested, in an important endorsement of preemptive authority, that "[o]ne of the best means to repel invasion is to provide the requisite force for action before the invader himself has reached the soil." Id.

94. The Supreme Judicial Court of Massachusetts rejected the proposition that the President, and not the Governor of Massachusetts, was empowered to determine whether an exigency had arisen sufficient to require the calling forth of the militia. See Opinion of the Justices, 8 Mass. (7 Tyng) 548 (1812). For a discussion of the controversy and of the extent to which Mott may or may not have settled the issue, see Hirsch, supra note 21 , at 950-56 \& n. 166.

95. As Justice Story concluded,

We are all of opinion, that the authority to decide whether the exigency has arisen, belongs exclusively to the President, and that his decision is conclusive upon all other persons. We think that this construction necessarily results from the nature of the power itself, and from the manifest object contemplated by the [1795 Militia Act]. The power itself is to be exercised upon sudden emergencies, upon great occasions of state, and under circumstances which may be vital to the existence of the Union.

Mott, 25 U.S. (12 Wheat.) at 30. 
[The President] is necessarily constituted the judge of the existence of the exigency in the first instance, and is bound to act according to his belief of the facts. ... The law does not provide for any appeal from the judgment of the President, or for any right in subordinate officers to review his decision, and in effect defeat it. ... [W] are all of opinion that such is the true construction of the act of $1795 .^{96}$

Per the Mott Court, then, the 1795 Militia Act granted broad power to the Executive to determine, for himself, when circumstances necessitated the calling forth of the militia, and such a determination was not subject to judicial review. Though Mott spoke more to the authority conferred by the Militia Act with regard to invasions (since the War of 1812 was, after all, a war in which America repelled British invaders), the broader source of authority under the Act-the power to ensure proper execution of the laws-necessarily followed by implication, and it would explicitly come before the Court twenty-two years later in Luther v. Borden.

Luther v. Borden, which arose out of Dorr's Rebellion in Rhode Island, raised the question of whether the Supreme Court could have any role in determining which of the two competing state governments in Rhode Island was legitimate and to what extent the "rebels" could sue under the Guarantee Clause, alleging that the federal government owed them a "republican" state government. ${ }^{97}$ The critical question before the Luther Court, at least to the argument herein, was the former-whether the Court could review President Tyler's determination that there was sufficient turmoil in Rhode Island to invoke the Guarantee Clause's promise of federal protection against "domestic violence." 98

Writing for the Court, Chief Justice Taney found that it was the province of the legislature to oversee the President's determination. Congress could have made claims under the "domestic violence" subclause justiciable, "[b]ut Congress thought otherwise, and no doubt wisely," and passed the 1795 Militia Act to delegate its authority in that arena. ${ }^{99}$ As Taney concluded, "By this act, the power of deciding whether the exigency had arisen upon which the government of the United States is bound to interfere, is given to the President." 100 The power to impose martial law, the Luther Court held, was necessarily part of this authority, and came directly

96. Id. at 31-32.

97. For the facts, see Luther v. Borden, 48 U.S. (7 How.) 1, 34-38, 42 (1849).

98. See U.S. CONST. art. IV, $\S 4$.

99. Luther, 48 U.S. (7 How.) at 43.

100. Id. (emphasis added). Taney also provided an eloquent defense of why it was appropriate for Congress to have vested such broad and unchecked power in the Executive. See id. at 44; see also Mott, 25 U.S. (12 Wheat.) at 32 (responding with similar eloquence to concerns that power under the Militia Act was unduly broad). 
from the Militia Acts. This point bears emphasizing, for no court before or since has so directly traced "martial law" to any part of the Constitution or to an act of Congress.

Such power, the Court concluded, could not be subjected to review by the courts, following (and largely adopting) Justice Story's logic from Mott. ${ }^{101}$ Interestingly, however, the Luther Court did not suggest that such power was without a check. Instead, "if the President in exercising this power shall fall into error, or invade the rights of the people of the State, it would be in the power of Congress to apply the proper remedy." 102 But what legislative remedy could there be if such power wasn't fully within the purview of Congress to begin with?

In dissent, Justice Woodbury adverted to an important distinction that he claimed the majority overlooked-the differences between various degrees of martial law. In responding to arguments that the Rhode Island legislature had not actually meant to impose "martial law," Woodbury suggested that the Court must be clear to distinguish between the martial law governing the military and "martial law," which "is made . . to apply to all." 103 Per Justice Woodbury, the first type of "martial law" is the most common-the Executive's authority over his own troops, which is unquestionably wide ranging once the troops are in service. Second is what has elsewhere been called "qualified" martial law-the government's authority to use its troops as a defensive force for the public, maintaining public order and keeping the peace. ${ }^{104}$ This type of martial law, according to Justice Woodbury, would include the power, if circumstances necessitated, to suspend the writ of habeas corpus, but is "far short" of what Rhode Island had both said and done in the Luther case. ${ }^{105}$ Third, and most severe, is what has elsewhere been described as "punitive" martial law-the authority to use troops domestically to punish, whether through military trials of civilians or unusually harsh penalties for minor infractions. ${ }^{106}$

According to Justice Woodbury, it was the last category that transpired in Rhode Island. ${ }^{107}$ What most offended Woodbury was that he believed the

101. See Luther, 48 U.S. (7 How.) at 44-45.

102. Id. at 45 .

103. Id. at 60 (Woodbury, J., dissenting).

104. See, e.g., Henry Winthrop Ballantine, Qualified Martial Law, A Legislative Proposal (pts. 1 \& 2), 14 MICH. L. REV. 102, 197 (1915-1916).

105. Luther, 48 U.S. (7 How.) at 59-60 (Woodbury, J., dissenting). For the actions Justice Woodbury believed the Rhode Island government had taken in error, see infra note 107.

106. See John P. Frank, Ex Parte Milligan v. The Five Companies: Martial Law in Hawaii, 44 COLUM. L. REV. 639, 650 (1944) (surveying the different types of martial law).

107. Luther, 48 U.S. (7 How.) at 60 (Woodbury, J., dissenting) ("[T]hey not only said, eo nomine, that they established 'martial law,' but they put in operation its principles; principles not relating merely to imprisonment, like the suspension of the habeas corpus, but forms of arrest 
situation in Rhode Island was not severe enough to render resort to such drastic measures appropriate or necessary:

It looks, certainly, like pretty bold doctrine in a constitutional government, that, even in time of legitimate war, the legislature can properly suspend or abolish all constitutional restrictions, as martial law does, and lay all the personal and political rights of the people at their feet. But bolder still is it to justify a claim to this tremendous power in any State, or in any of its officers, on the occurrence merely of some domestic violence. ${ }^{108}$

Given the vagaries of the statutory regime outlined in Part I, Justice Woodbury's proposed trifurcation of martial law is significant. Here, for the first time, were concrete suggestions for when the President could use certain aspects of his delegated authority under the Militia Acts, and what the limits were. His eloquence and foresight notwithstanding, however, the more important aspect of Luther is the majority's holding that the power to determine whether obstruction of the laws is sufficient to merit the calling forth of the militia ${ }^{109}$ and to impose martial law is executive, but only by virtue of the Militia Acts. Just as in Mott, the Court began and ended its discussion of executive authority by invoking the 1795 statute. For both Courts, it was the Militia Acts, and not any other authority, that had given Presidents Madison and Tyler the authority to act as they did. ${ }^{110}$ The President had unfettered discretion to invoke his authority, but only because Congress had specifically intended and delegated such.

There can be little question that, as George Dennison wrote in 1974, " $[t]$ he Luther decision altered the American law of emergency powers, although few seemed aware of the change."111 At its core, Luther stood for the proposition that the power to impose martial law was a valid constitutional grant, one that the President, by virtue of the Militia Acts, was lawfully authorized to execute and carry out. The Taney Court, as Dennison concluded, may have "intended to show that the Luther decision

without warrant, breaking into houses where no offenders were found, and acting exclusively under military orders rather than civil precepts.").

108. Id. at 70 .

109. The Luther Court found it insignificant that the militia had never actually been called out. See id. at 44 (majority opinion). As Chief Justice Taney concluded, "The interference of the President, therefore, by announcing his determination, was as effectual as if the militia had been assembled under his orders. And it should be equally authoritative." Id.

110. It bears emphasizing here, as repeatedly highlighted by both Wilson and Coakley, that compliance with the Militia Acts regime was generally the rule prior to the Civil War. Compare Martin v. Mott, 25 U.S. (12 Wheat.) 19 (1827), with FREDERICK T. WILSON, FEDERAL AID IN DOMESTIC DISTURBANCES: 1787-1903, S. DOC. NO. 57-209, at 65-72 (2d Sess. 1903), and COAKLEY, supra note 20, at 120-27.

111. Dennison, supra note 62, at 76. 
in 1849 applied only to the actions of states, and did not promulgate a refined definition of martial law... . But Taney's attempted qualifications of the broadly-worded [Luther] decision failed to impede the rising acceptance of the new conception of emergency powers." 12 The validity of this new conception included, at least tacitly because of Mott and Luther, the centrality of the Militia Acts as a broad source of emergency power beyond the power to suppress insurrections and repel invasions, ${ }^{113}$ and it would be a major issue before Northern courts during the Civil War.

\section{B. Emergency Power During the Civil War}

\section{The Militia Acts and Martial Law: Field and the Trigger Problem}

In his recent work on Abraham Lincoln and the legality of Lincoln's actions during the Civil War, Daniel Farber seized on the Militia Acts as a broad source of Lincoln's authority to impose martial law at the outset of the war, ${ }^{114}$ relying largely on Ex parte Field, ${ }^{115}$ an obscure decision of the Circuit Court for the District of Vermont. Drawing on Mott and Luther, the Field court argued that the Militia Acts delegated to the President the authority to impose martial law at the outset of hostilities, and that the imposition of martial law ipso facto included the suspension of the writ of habeas corpus. As the court concluded, because of the Acts, "the president has the power, in the present military exigencies of the country, to proclaim martial law, and, as a necessary consequence thereof, the suspension of the writ of habeas corpus in the case of military arrests."116

112. Id. at 77 .

113. The importance of the Luther Court's reading of the Militia Acts is best discerned from the so-called Cushing Doctrine, derived from a series of opinions issued by Attorney General Caleb Cushing in the mid-1850s. The doctrine arose out of claims by President Fillmore, during the disturbances in Boston after the passage of the 1850 Fugitive Slave Act, that the President possessed inherent authority to use the regulars during domestic uprisings. In response, Cushing articulated the position that, in enforcing the Act, a U.S. marshal could "call on federal military forces in his district without any reference to the president whatsoever," but that this was by virtue of the statutory regime created by Congress. COAKLEY, supra note 20, at 132; see also 8 Op. Att'y Gen. 8, 11-15 (1856); 6 Op. Att'y Gen. 466 (1854). Though it makes no reference to Luther, the Cushing Doctrine, the leading position on the subject until it was rejected by the Posse Comitatus Act, suggests just how much Luther gave rise to broad claims of domestic military authority under the Militia Acts.

114. FARBER, supra note 3, at 162-63.

115. 9 F. Cas. 1 (C.C.D. Vt. 1862) (No. 4761).

116. Id. at 8. Field thus distinguished itself from Ex parte Merryman, 17 F. Cas. 144 (Taney, Circuit Justice, C.C.D. Md. 1861) (No. 9487), in which Chief Justice Taney held Lincoln's unilateral suspension of habeas unconstitutional, by arguing that, at the time of the Merryman incident, the President had not yet imposed martial law. See Field, 9 F. Cas. at 8-9; see also Vladeck, supra note 13, at 165 \& nn.66-69 (discussing Field). Judge Smalley, author of Field, was not the first American jurist to explicitly suggest the link between martial law and habeas; Justice Woodbury had argued much the same position in Luther v. Borden, 48 U.S. (7 How.) 1, 
Field was something of an outlier in relying on congressional authorization to uphold the legality of President Lincoln's actions, ${ }^{117}$ but it certainly wasn't alone. ${ }^{118}$ Though lower courts split on the sources of Lincoln's emergency powers during the war, the Field opinion was the only one to address the nature of martial law in true detail, and its discussion of the relationship between martial rule and habeas is as learned as it is forceful. If the civil law is suspended via the imposition of military rule, what court would be empowered to issue a writ of habeas corpus, even assuming that one could apply for the writ? Especially after the Court's discussion of martial law in Ex parte Milligan, ${ }^{119}$ the Field argument that habeas must necessarily be suspended when martial law is in force resonates quite loudly. ${ }^{120}$

Equally loud, however, are arguments that the power to suspend habeas is emphatically vested in Congress, per the Suspension Clause. ${ }^{121}$ Field thus suggests that the Militia Acts, which the Luther Court had clearly established as the source of the power to impose martial law, necessarily authorized the suspension of habeas under certain conditions. By implication, then, it suggests that Lincoln's suspension of habeas at the

59-60 (1849) (Woodbury, J., dissenting). Cf. Hamdi v. Rumsfeld, 124 S. Ct. 2633, 2671 n.4 (2004) (Scalia, J., dissenting) (describing imposition of martial law as "a step even more drastic than suspension of the writ").

117. A handful of lower court cases prior to the Prize Cases had suggested that most of Lincoln's authority to act came from his executive power. See, e.g., United States v. The Tropic Wind, 28 F. Cas. 218, 220-22 (C.C.D.D.C. 1861) (No. 16,541a); The Amy Warwick, 1 F. Cas. 799, 804 (D. Mass. 1862) (No. 341).

118. This is a significant point, for Judge Smalley, writing for the Field court, suggested that it was. See Field, 9 F. Cas. at 8 ("I am aware that the conclusion at which I have arrived may seem to conflict with some very high authorities, but it appears to me that they can be reconciled."). Because the argument, at its core, is that Congress de facto authorized the suspension of habeas in authorizing the imposition of martial law, all of the contraindicated authorities are satisfied-the suspension was by Congress; it just wasn't explicit.

Further, the Field court was not the only Civil War-era lower court to focus on the Militia Acts as a key source of Lincoln's emergency power. See, e.g., United States v. One Hundred and Fifty-Six Packages of Tea, 27 F. Cas. 271, $272-73$ (S.D.N.Y. 1865) (No. 15,933) (centering on the 1861 Act as providing broad authority to Lincoln to declare seceded states to be in insurrection, and to seize goods from such states); McCall's Case, 15 F. Cas. 1225, 1226-30 (E.D. Pa. 1863) (No. 8669) (summarizing Lincoln's broad authority over troops at the beginning of the war and emphasizing the role of Congress); United States v. One Hundred and Twenty-Nine Packages, 27 F. Cas. 284, 288-90 (E.D. Mo. 1862) (No. 15,941) (holding that Lincoln's authority to determine that-and when-Tennessee had entered into a state of insurrection derived from the Militia Acts).

119. 71 U.S. (4 Wall.) 2 (1866). As discussed in more detail below, the Milligan Court famously held that martial law can be appropriate away from the battlefield only when the courts are not open or their process unobstructed.

120. For more detailed discussions of the relationship between martial law and habeas, see John H. Hatcher, Martial Law and Habeas Corpus, 46 W. VA. L.Q. 187 (1940); and J.W. Brabner Smith, Martial Law and the Writ of Habeas Corpus, 30 GEO. L.J. 697 (1942).

121. See, e.g., Developments in the Law-Federal Habeas Corpus, 83 HARv. L. REv. 1038, 1264 (1970). 
outset of the Civil War was unilateral only to the extent to which it was not coincident with the imposition of martial rule. Such was the case in $E x$ parte Merryman $^{122}$ and Ex parte Benedict, ${ }^{123}$ where Lincoln's actions were rejected, but not in Field.

More importantly, Field highlights the problem with the Militia Acts regime that Justice Woodbury's dissent in Luther had first hinted at: What are the different triggers authorizing varying degrees of presidential action? Are the imposition of martial law and the resultant habeas suspension automatically authorized as soon as the President can invoke the Acts? Certainly, nothing in the Acts themselves suggests the contrary, but would it not defy common sense for the broadest authority under the Acts to be available any time the regime was invoked?

Leaving these questions aside for a moment, one thing is clear: According to James Garfield Randall, author of what remains today the most comprehensive legal analysis of Lincoln's actions, "[T] he emergency, as interpreted by the Lincoln administration, was precisely that for which the use of militia had been expressly authorized. To execute the laws, to suppress an insurrection, to put down combinations too powerful for judicial methods-these were the purposes for which the Government needed troops." 124 It would be up to the Supreme Court to police the boundaries of President Lincoln's authority once invoked.

\section{The Importance of the Prize Cases}

Judge Smalley's discussion in Field notwithstanding, the most significant of the Civil War-era cases, at least to the question of presidential emergency power, was the Supreme Court's 1863 decision in the Prize Cases, the consolidation of four admiralty suits filed shortly after the beginning of the war. ${ }^{125}$ The core issues before the Prize Cases Court were the constitutionality of President Lincoln's imposition of a naval blockade

122. 17 F. Cas. 144 (Taney, Circuit Justice, C.C.D. Md. 1861) (No. 9487).

123. 3 F. Cas. 159 (N.D.N.Y. 1862) (No. 1292).

124. J.G. Randall, Constitutional Problems Under Lincoln 243 (Peter Smith ed., Univ. of Ill. Press rev. ed. 1963) (1926); see also COAKLEY, supra note 20, at 227 ("In theory the Lincoln administration did treat the secession of the Southern states as an insurrection to be handled under the laws of 1795 and $1807 \ldots$... And it secured a permanent revision of those laws vastly strengthening the executive's hand."). The reality, though, fit more into what Randall described as the dual theory of the war-that, constitutionally, the war was an insurrection, but from the perspective of the actual conduct of troops and the rights owed to enemy soldiers, the traditional (and international) laws of war should and would apply. See RANDALL, supra, at 48-73.

125. For a thorough modern discussion of the cases' background and particulars, see ROBERT Bruce MurRay, LEGal CASES OF THE CiVIL WAR 1-18 (2003). See also William G. Young, Amy Warwick Encounters the Quaker City: The District of Massachusetts and the President's War Powers, 74 MASS. L. REV. 206 (1989) (surveying the facts and the proceedings below). 
at the outset of hostilities and the source of his authority to do so. (Congress, at the time of the four captures before the Court in the Prize Cases, had yet to specifically authorize the blockade, though it would do so later as part of a broader ratification of Lincoln's actions.) ${ }^{126}$ The critical passage, at least on the authority point, came early in Justice Grier's opinion for the Court, in what remains today the definitive statement of defensive war power under the Constitution. As Justice Grier wrote,

The Constitution confers on the President the whole Executive power.... He has no power to initiate or declare a war either against a foreign nation or a domestic State. But by the Acts of Congress of February 28th, 1795, and 3d of March, 1807, he is authorized to call[] out the militia and use the military and naval forces of the United States in case of invasion by foreign nations, and to suppress insurrection against the government of a State or of the United States. ${ }^{127}$

Subsequent courts and commentators have routinely invoked the next passage of Justice Grier's opinion as the decision's critical conclusion, for the Court continued, "If a war be made by invasion of a foreign nation, the President is not only authorized but bound to resist force by force. He does not initiate the war, but is bound to accept the challenge without waiting for any special legislative authority." 128 As the opinion concluded,

126. See Act of Aug. 6, 1861, ch. 63, $\S 3,12$ Stat. 326, 326.

127. The Prize Cases, 67 U.S. (2 Black) 635, 668 (1863) (emphasis added). As highlighted above, the 1807 Act quite clearly did not authorize use of the federal military and naval forces to repel invaders. But this misstatement only further underscores the confusion surrounding the 1807 Act. See supra text accompanying notes 64-67.

128. Prize Cases, 67 U.S. (2 Black) at 668; see also FARBER, supra note 3, at 138-41 (discussing the Prize Cases and, in passing, the role of the Militia Acts). In Padilla, Judge Wesley cited this passage for the proposition that

common sense and the Constitution allow the Commander in Chief to protect the nation when met with belligerency and to determine what degree of responsive force is necessary. ... Regardless the title given the force, the President, in fulfilling his duties as Commander in Chief to suppress insurrection and to deal with belligerents aligned against the nation, is entitled to determine the appropriate response.

Padilla v. Rumsfeld, 352 F.3d 695, 727-28 (2d Cir. 2003) (Wesley, J., concurring in part and dissenting in part), rev'd on other grounds, 124 S. Ct. 2711 (2004). But the Prize Cases Court specifically found the President's authority "to suppress insurrection and to deal with belligerents" in the Militia Acts and not in Article II of the Constitution.

Another contemporary example of this common and critical misunderstanding of the Prize Cases is Judge Silberman's conclusion in Campbell v. Clinton that "the Prize Cases ... stand for the proposition that the President has independent authority to repel aggressive acts by third parties even without specific congressional authorization, and courts may not review the level of force selected." 203 F.3d 19, 27 (D.C. Cir. 2000) (Silberman, J., concurring). The latter claim is clearly correct, but the former claim simply isn't complete; it neglects the extent to which what had made more specific authorization unnecessary were prior Acts of Congress-the 1795 and 1807 Acts. 
Whether the President in fulfilling his duties, as Commanderin-chief, in suppressing an insurrection, has met with such armed hostile resistance, and a civil war of such alarming proportions as will compel him to accord to them the character of belligerents, is a question to be decided by him, and this Court must be governed by the decisions and acts of the political department of the Government to which this power was entrusted.

The distinction between "authorized" and "bound" is telling-the authorization to act, according to the Court, came from the Militia Acts. But it was the President's constitutional responsibility as Commander in Chief that obligated him to act. In effect, Grier suggested, Congress made presidential action appropriate, and, once it had, the Constitution rendered such action both necessary and unreviewable. Critically, if the President's authority to act stemmed solely from Article II, the existence of congressional authorization would (and could) not have been a necessary precondition-he would have been bound to act whether Congress authorized the action or not. Read together, these passages endorse broad executive war power but emphasize the reason why the President did not need to wait for "special legislative authority." It was not because the Constitution independently conferred such power upon him. Rather, earlier acts of Congress had delegated such authority and did not require specific reaffirmation at the outset of hostilities in $1861 .^{130}$

Indeed, without question, the Prize Cases endorse a broad understanding of the President's war powers with respect to his independent authority to act during crises. But the underlying constitutional source of these powers, per the Court itself, is not the President but Congress, which delegated them to the President via the Militia Acts. The Prize Cases thus

129. Prize Cases, 67 U.S. (2 Black) at 670 . This particular passage, a favorite of Fairman's, see FAIRMAN, supra note $16, \S 31$, at 119 , was also relied on by William Rehnquist, shortly before he was named to the Court, in a speech defending the Nixon Administration's position on the constitutionality of the war in Cambodia, see William H. Rehnquist, The Constitutional IssuesAdministration Position, 45 N.Y.U. L. REV. 628, 631 (1970).

For a fascinating contemporary discussion of this passage and where it fits into the Court's presidential authority jurisprudence, see El-Shifa Pharmaceutical Industries Co. v. United States, 378 F.3d 1346, 1366 (Fed. Cir. 2004). In El-Shifa, the invocation of the Prize Cases came in the context of the court's discussion of "the inherent power vel non of the President to designate as enemy property the private property of an alien that is situated on foreign soil." $I d$. at 1362 .

130. To be sure, politics may have required the Prize Cases Court to sustain the blockade even without any underlying congressional authority, given the disastrous political ramifications of a ruling formally according the Confederacy the status of belligerents. But the Militia Acts provided the Court with a statutory means around the political mess, since it was a fair reading of the statutes, especially in light of Luther and the Suppression of the Rebellion Act of 1861, that they conferred upon President Lincoln the authority to impose the blockade-to use the military to suppress an insurrection. The reliance on the Militia Acts was all the more telling given that the courts below had upheld the blockade by reference to the President's constitutional authority. See, e.g., The Amy Warwick, 1 F. Cas. 799, 804 (D. Mass. 1862) (No. 341). 
embrace the logic of Field - that President Lincoln had massive and nearly unchecked authority to suppress an insurrection and that it was at least largely under this aegis that he undertook most of his actions (and that his actions should be sustained). But the reason why Lincoln had such power was just as clear: Congress, not the Constitution, had given it to him. It didn't matter that Congress hadn't given President Lincoln such power in 1861; the single most important point of the Prize Cases was that Congress gave the President such authority in 1795 and 1807. The Prize Cases, among the most significant war power precedents in the annals of the Supreme Court, turned not on any provision of the Constitution, but on the Militia Acts.

\section{Milligan and a Suggested Trigger}

The Prize Cases Court's broad reading of executive authority saw one important clarification three years later in the context of the use of military tribunals against civilians in the North. After the war, a very different Court, in Ex parte Milligan, adopted a much more cynical tone in judging the constitutionality of President Lincoln's unilateral creation and implementation of such quasi-courts far from the battlefields. ${ }^{131}$ The Milligan Court, clarifying Luther, famously concluded that " $[\mathrm{m}]$ artial rule can never exist where the courts are open, and in the proper and unobstructed exercise of their jurisdiction. It is also confined to the locality of actual war."132

Because the civil courts were functioning properly in Indiana at the time of the trial of Lamdin P. Milligan, all nine Justices concluded that his trial by military commission could not stand. The flip side of Milligan, though, was the conception that martial law should be available as a constitutional power in times when these conditions were not met. As much as the Milligan Court dramatically argued against the subversion of civil law in the context of the Indianapolis military tribunais, it just as strongly suggested that martial law itself, as a concept, was not completely foreign to the Constitution-an important concession from an otherwise unsympathetic Court.

But there was a second opinion in Milligan, written by Chief Justice Chase on behalf of himself and Justices Wayne, Swayne, and Miller. Together, the four Justices agreed with the rest of the Court that Milligan's trial by military tribunal was unauthorized, but they disagreed that it could never be constitutional. Instead, the concurring Justices emphasized the

132. Id. at 127 . 
importance of the absence of congressional authorization-that a military tribunal created unilaterally by President Lincoln could not try Milligan, but perhaps such a tribunal authorized by Congress could have. ${ }^{133}$ As part of their discussion, the concurring Justices highlighted the wide-ranging war and emergency powers granted to Congress, including those conferred via the First Militia Clause, ${ }^{134}$ and concluded that such powers conceivably could extend to the creation of military commissions. Because no act of Congress existed that could fairly be read to authorize such tribunals, however, the four concurring Justices agreed with their brethren that Milligan's trial was unconstitutional. ${ }^{135}$

Whereas all nine Justices agreed that President Lincoln could not unilaterally create military commissions, only five also agreed that Congress lacked such authority away from the battlefield. For this latter proposition, commentators have scomed Milligan as an example of post hoc overreaching, ${ }^{136}$ and a later Court has overruled-or at least heavily distinguished-the decision on this point. ${ }^{137}$ But in rejecting the unilateral power of the President to create and administer military commissions, every member of the Milligan Court only reinforced the conclusion at the core of the Prize Cases. Together, the Prize Cases and Milligan compel a simple, elegant framework for presidential power during the Civil War: When the President acted alone, without anything in the way of congressional authorization, the Court subjected his actions to rigorous constitutional scrutiny, and his power was at its most reduced state. When the President acted pursuant to some congressional authority, the Court subjected his actions to almost no scrutiny, and his power was at its peak. This conception of presidential emergency power should sound markedly familiar. ${ }^{138}$

133. As Chief Justice Chase wrote,

[T] he opinion which has just been read... asserts not only that the military commission held in Indiana was not authorized by Congress, but that it was not in the power of Congress to authorize it; from which it may be thought to follow, that Congress has no power to indemnify the officers who composed the commission against liability in civil courts for acting as members of it. We cannot agree to this.

Id. at 136 (opinion of Chase, C.J.).

134. See id. at 137-40.

135. See id. at 134-36.

136. For two stark examples, see RossITER, supra note 84, at 34-37; and MARTIN S. SHEFFER, THE JUDICIAL DEVELOPMENT OF PRESIDENTIAL WAR POWERS 28-29 (1999).

137. See Ex parte Quirin, 317 U.S. 1 (1942) (upholding the domestic use of military tribunals during wartime to try eight Nazi saboteurs-including two U.S. citizens-captured within the United States). In Quirin, as opposed to Milligan, there was congressional authorization.

138. This is precisely the outline Justice Jackson had in mind in Steel Seizure in delineating the three categories of presidential authority. See Youngstown Sheet \& Tube Co. v. Sawyer (Steel Seizure), 343 U.S. 579, 635-38 (1952) (Jackson, J., concurring). 
What is less familiar is the importance of the Militia Acts. The Acts were the crucial linchpin on which the Prize Cases Court relied, invoked as the sole basis for the President's broad and unchecked power to suppress insurrections. Without a similar statutory grant in Milligan, the Court looked far more hesitantly on presidential power, especially the four concurring Justices, who assumed that the Constitution could not bestow upon the Executive powers granted to-and unexercised by-Congress.

What Milligan implicitly suggests, then, is a limitation on the President's power under the Militia Acts ${ }^{139}$-a judicial trigger among the three categories of martial rule. ${ }^{140}$ Whereas Lincoln had the power to impose a blockade at the outset of hostilities by virtue of the 1795 and 1807 delegations, his authority could not extend to the creation and use of military tribunals that Congress had not otherwise authorized when the courts were open and their process unobstructed. The status of the civil judicial system was the critical factor: When the courts were open, punitive martial rule could not exist. Thus, the President was limited to only those powers short of the imposition of punitive martial law. But when the courts were closed, martial rule, whatever its limits, would obtain. ${ }^{141}$ The Court refused to read the power to create military tribunals off the battlefield into the same broad grant of authority that authorized the imposition of a blockade to suppress an insurrection, suggesting that there were no circumstances under which such tribunals could be reconciled with the Constitution.

At bottom, then, Milligan may properly be cast as the first of a progressive series of cases in which the Court began to impose limits on the President's power with respect to martial law and military emergencies. Under Mott, Luther, and the Prize Cases, it had held the determination that an emergency existed and the exercise of power during that emergency were largely, if not entirely, beyond judicial review. In cases arising out of state insurrections, ${ }^{142}$ and later the imposition of martial law in Hawaii during

139. Indeed, David Dudley Field, Milligan's lawyer, invoked the calling-forth power several times during his argument before the Court in support of his position against the executive power at issue. See Milligan, 71 U.S. (4 Wall.) at 32-33.

140. See supra notes 103-106 and accompanying text (discussing the distinctions between the different types of martial law suggested by Justice Woodbury in his dissent in Luther).

141. Though the force of Milligan was called into some doubt by Quirin, this principle, one of the Supreme Court's truly landmark statements, survived intact and was reaffirmed in Duncan v. Kahanamoku, 327 U.S. 304 (1946). For a discussion of the relationship between Milligan, Quirin, and Duncan, see Vladeck, supra note 13, at 172-73 \& n.113. See also Hamdi v. Rumsfeld, 124 S. Ct. 2633, 2669-70 \& n.4 (2004) (Scalia, J., dissenting) (discussing the disputed relationship between Milligan and Quirin).

142. The state cases are less relevant here because they dealt more directly with the power of state executives and spoke of the Federal Constitution only when it came to the reviewability of the state's actions, see, e.g., Sterling v. Constantin, 287 U.S. 378 (1932), and the due process rights - or lack thereof - of those detained, see, e.g., Moyer v. Peabody, 212 U.S. 78 (1909). 
World War II, ${ }^{143}$ the Court stepped back and explicitly suggested limitsalbeit soft ones-on the government's previously unreviewable power under the Militia Acts. But neither Milligan nor these subsequent cases fully resolved Justice Woodbury's concerns in Luther, for none suggested just what the line was between the first and second degrees of martial law (Milligan had clearly drawn the line for the third) or who should police it.

\section{The Problem of "Inherent" Presidential Power: Debs and Neagle}

Finally, no discussion of the nineteenth-century evolution of American emergency power in the courts could overlook the two cases most often cited for the existence of "inherent" presidential power, Cunningham $v$. Neagle ${ }^{144}$ and In re Debs. ${ }^{145}$ In Neagle, the Court was confronted with the legality of an Executive Order (not based on any underlying statutory authority) authorizing a U.S. marshal to protect Justice Stephen Field. The marshal killed a would-be assassin and, after he was arrested by California authorities, filed a habeas petition seeking his release, alleging that he was being held for actions taken under the lawful authority of the United States. ${ }^{146}$ Justice Miller, writing for the Court, concluded that the marshal was acting pursuant to lawful authority, for the President was entitled, under the Take Care Clause, to authorize protection for a sitting Supreme

For a survey of the issues arising from the state insurrections, as well as discussions of the relevant state court decisions, see Charles Fairman, Martial Rule and the Suppression of Insurrection, 23 ILL. L. REV. 766 (1929); and Edward S. Corwin, Martial Law, Yesterday and Today, 47 POL. SCI. Q. 95 (1932). The state cases culminated in the Court's thorough denunciation of extraconstitutional emergency powers in Home Building \& Loan Ass' $n$ v. Blaisdell, 290 U.S. 398, 425 (1934). See also Michal R. Belknap, The New Deal and the Emergency Powers Doctrine, 62 TEX. L. REV. 67, 92-98 (1983) (discussing Blaisdell).

143. In Duncan v. Kahanamoku, the Supreme Court rejected the Governor of Hawaii's use of federal military courts to try civilians for civilian crimes during World War II, even though the Hawaiian Organic Act explicitly vested in the Governor the authority to impose martial law, along with the discretion to control its exercise. Act of Apr. 30, 1900, ch. 339, $\$ 67,31$ Stat. 141, 153 (repealed 1959). Reaffirming Milligan, a necessary step in light of the Court's decision in Ex parte Quirin, 317 U.S. 1 (1942), the Duncan Court rejected the theory of "punitive" martial law:

The phrase "martial law" as employed in [the Organic] Act, therefore, while intended to authorize the military to act vigorously for the maintenance of an orderly civil government and for the defense of the Islands against actual or threatened rebellion or invasion, was not intended to authorize the supplanting of courts by military tribunals.

Duncan, 327 U.S. at 324. Again, however, the Court took no issue with the notion that the Constitution empowered Congress to provide for the imposition of martial law via legislation; rather, the Court's concern, as in Milligan and Constantin, was with the limits on its exercise. Even during wartime, the Court refused to accept the argument that the power to impose martial law came from anywhere except an act of Congress.

144. Cunningham v. Neagle (In re Neagle), 135 U.S. 1 (1890).

145. 158 U.S. 564 (1895).

146. For a concise, contemporary recitation of the facts leading to Neagle, see WILLIAM H. REHNQUIST, CENTENNIAL CRISIS: THE DISPUTED ELECTION OF 1876, at 149-52 (2004). See also CARL BRENT SWISHER, STEPHEN J. FIELD: CRAFTSMAN OF THE LAW 328-61 (1930). 
Court Justice even in the absence of a specific constitutional grant or an act of Congress. As Miller concluded,

That there is a peace of the United States; that a man assaulting a judge of the United States while in the discharge of his duties violates that peace; that in such case the marshal of the United States stands in the same relation to the peace of the United States which the sheriff of the county does to the peace of the State of California; are questions too clear to need argument to prove them. ${ }^{147}$

Neagle and Debs, as discussed below, are often cited as two key precedents supporting the concept of "inherent" presidential emergency power and the concept that the President, by virtue of the Take Care Clause, has emergency powers nowhere explicit in the Constitution. But Neagle's contribution to this theory is questioned even by the most ardent supporters of broad presidential power, ${ }^{148}$ and Professor Henry Paul Monaghan's arguments about Neagle endorsing only a narrower "protective" executive power have been widely received. ${ }^{149}$ This is not to reject the theory of inherent presidential power outright; but at least in the area of domestic emergency power, the Militia Acts appear to emerge from Neagle unscathed. The Neagle Court suggested that there are some limited presidential protective powers inherent in the authority under the Take Care Clause, but given the scope and breadth of contraindicated precedents on the question of emergency power, "inherent" presidential power seems a far cry from "emergency" presidential power.

147. Neagle, 135 U.S. at 69. Building on Miller's opinion, Professor Monaghan dubbed this the "protective power of the presidency" in his eloquent article of the same name. See Monaghan, supra note 3 , at 1 .

148. See, e.g., SHEFFER, supra note 136, at 34.

149. For Monaghan's argument, see supra note 147. For examples of its reception, see Steven G. Calabresi \& Saikrishna B. Prakash, The President's Power To Execute the Laws, 104 YALE L.J. 541, 545 n.6 (1994); and H. Jefferson Powell, The President's Authority over Foreign Affairs: An Executive Branch Perspective, 67 GEO. WASH. L. REV. 527, 535 n.38 (1999).

Dozens of contemporary scholars, Prakash and John Yoo prominent among them, have argued for far broader conceptions of executive power, especially in the foreign affairs field. See, e.g., Saikrishna B. Prakash \& Michael D. Ramsey, The Executive Power over Foreign Affairs, 111 YALE L.J. 231 (2001); John C. Yoo, War and the Constitutional Text, 69 U. CHI. L. REV. 1639 (2002). But at least with regard to domestic crisis authority during emergencies, they rely on little in the way of legal precedent separate from Neagle and Debs, and Monaghan seems to have the better of the argument with regard to Neagle-that it espouses only a limited theory of presidential power. See Monaghan, supra note 3, at 65-66. Monaghan does argue that the President's power under the Militia Acts "arguably ... exists absent statute," $i d$. at 65 , but this is a nonstarter, for he himself implicitly acknowledges the centrality of the statutes, tracing the relationship between Neagle and its predecessor case, Ex parte Siebold, 100 U.S. 371 (1879), to the modern-day form of the Militia Acts, 10 U.S.C. $\S \S 331-335$ (2000). See Monaghan, supra note 3 , at 65 n.313. 
Five years later, in In re Debs, the Court was confronted with the constitutionality of the use of federal troops by President Cleveland to help restore order in Chicago during the Pullman strike of $1894 .^{150}$ In broad language, Justice Brewer sustained the action, largely by reference to Neagle, on the grounds that " $[\mathrm{t}]$ he entire strength of the nation may be used to enforce in any part of the land the full and free exercise of all national powers and the security of all rights entrusted by the Constitution to its care." ${ }^{51}$ But there is an important historical footnote to Debs that neither the Court nor most commentators on the case paid attention to: What was truly at issue in Debs was President Cleveland's authority under the Militia Acts to call out the federal army to ensure the "faithful execution of the laws." The Court even intimated as much in one passage, ${ }^{152}$ though it was ultimately vague as to the actual source of the President's power.

Whereas the Court may have been unclear as to the source of Cleveland's authority, the President himself wasn't, and he generally followed the guidelines of the Militia Acts. ${ }^{153}$ As David Gray Adler wrote, "When President Cleveland deployed troops to break the Pullman Strike over the protest of Governor Altgeld, on the altogether unpersuasive claim that the enforcement of federal laws was being obstructed, he forgot to issue the proclamation [required by the Militia Act]." "54 Debs was a challenge to whether Cleveland's power under the Militia Acts regime could lawfully extend to interference with the mails; it was not a challenge to its source. ${ }^{155}$

150. The justification for calling out the federal army was interference with the mails, a dubious proposition at best on which to hang such bold imposition of federal authority, especially given the vehement protests of Illinois Governor Altgeld to the contrary. See David Gray Adler, The Steel Seizure Case and Inherent Presidential Power, 19 CONST. COMMENT. 155, 183-86 (2002).

151. In re Debs, 158 U.S. 564, 582 (1895).

152. Id. ("The strong arm of the national government may be put forth to brush away all obstructions to the freedom of interstate commerce or the transportation of the mails. If the emergency arises, the army of the Nation, and all its militia, are at the service of the Nation, to compel obedience to its laws.").

153. See Proclamation No. 11, 28 Stat. 1249 (1894) (commanding the "insurgents," such as they were, to disperse, as required by the Militia Acts). As Clayton Laurie and Ronald Cole explain, the leading proponent for using the Militia Acts was Cleveland's Attorney General, Richard Olney, whose legal arguments ultimately carried the day. See LAURIE \& COLE, supra note 20 , at $136-38$.

154. Adler, supra note 150, at 184-85; see also ALMONT LINDSEY, THE PULLMAN STRIKE: THE STORY OF A UNIQUE EXPERIMENT AND OF A GREAT LABOR UPHEAVAL 164-65 (1942) (providing an overview of the Cleveland Administration's strategy for using military force to put down the strike).

155. As Professor Adler concluded,

[E]ven if one embraces the concept of a "peace of the United States" that the president has a duty to protect, it is a concept that must be viewed in the context of a Constitution that assigns to Congress alone both the law-making power and the authority to govern the use of military force, unless one invokes the vague notion of an extra-constitutional emergency power, which the Debs Court avoided altogether. 


\section{THE MiLITIA ACTS, EMERGENCY POWER, AND THE ACADEMY}

Early scholars, particularly Charles Fairman and Edward Corwin, paid plenty of attention to the Militia Acts in their analysis of emergency power, particularly with respect to martial law and the defensive war power. As Sections A and B suggest, Fairman and Corwin didn't fully understand the significance of their analysis, and both misread the significance of the Prize Cases, but at least they understood that the Acts had a role to play in their analysis. By contrast, subsequent discussions of executive emergency power, especially contemporary analysis, have wholly neglected the centrality of the Militia Acts to our understanding of the constitutional source of emergency power. ${ }^{156}$ This Part, by surveying the evolution of the discussion of emergency power in the academy, attempts to explain both how the Militia Acts disappeared from the academic discourse and why it is so important that they return.

\section{A. Corwin, Fairman, and the Misreading of the Prize Cases}

Martial law and emergency power were popular topics in the years leading up to and surrounding World War II, ${ }^{157}$ and the two leading midcentury commentators, without question, were Charles Fairman and Edward Corwin. Of most importance is the work of Corwin, still recognized today as one of the preeminent authorities on presidential power. Corwin's earliest significant contribution to emergency scholarship came in a 1932 review of Fairman's The Law of Martial Rule entitled Martial Law, Yesterday and Today. ${ }^{158}$ Noting that "[t]he judicial history of martial law under the Constitution opens with . . Luther v. Borden,"

Adler, supra note 150 , at 185 .

156. See, e.g., STEVENS, supra note 7; sources cited supra note 8.

157. Most prominent among the scholars besides Corwin and Fairman was Henry Ballantine, who wrote a series of articles on martial law shortly before and after World War I. See, e.g., Henry Winthrop Ballantine, Martial Law, 12 COLUM. L. REV. 529 (1912); Ballantine, supra note 104; Henry Winthrop Ballantine, Unconstitutional Claims of Military Authority, 24 YALE L.J. 189 (1915).

The only early scholar to attempt to trace the constitutional source of the authority to impose martial law, however, was Robert Rankin. See Robert Stanley Rankin, The Constitutional Basis of Martial Law, 13 CONST. REV. 75 (1929). Rankin's short piece, ten years before his longer work on the subject, see ROBERT S. RANKIN, WHEN CIVIL LAW FAILS: MARTIAL LAW AND ITS LEGAL BASIS IN THE UNITED STATES (1939), concluded that Neagle identified Article II as the primary constitutional source of the power to impose martial law. He argued that "[i]t is evident from the above discussion of the constitutional provisions that relate to martial law, that the duty of declaring martial law and of putting it into force is placed in the hands of the President." Rankin, supra, at 80 .

158. Corwin, supra note 142 (reviewing Charles FaIRMAN, THE LAW OF MARTIAL RULE (1930)).

159. Id. at 97 . 
the Prize Cases for the proposition, erroneous per the discussion above, that "the President, by virtue of his power as Chief Executive and his power as Commander-in-Chief, was entitled to treat a region which he found to be in insurrection as enemy country and thereby strip all of its inhabitants of their constitutional rights." $" 160$ As early as 1932 , Corwin understood the centrality of the Prize Cases to the debate, even in light of Milligan. ${ }^{161}$ What he didn't understand was the centrality of the Militia Acts to the Prize Cases. This interpretive error would become more significant in his later work.

Additionally, at the conclusion of his 1932 piece, Corwin first suggested his argument with respect to the source of the power to impose martial law, tying Neagle directly to "the President's power to employ martial law, as well as his power to employ military force in execution of the laws of the United States." 162 Corwin, at least in this early discussion, was convinced that Congress could act to place limits on presidential declarations, but he was just as convinced that, absent such statutory action, the President's authority was largely unfettered. As he concluded,

A statutory rule definitive of occasions requiring martial law would have to be in such broad terms as to leave it at the mercy of interpretation. On the other hand, for Congress to interfere with an existing declaration would require, in the face of a certain veto, a two-thirds vote in each house. ${ }^{163}$

Corwin's opinion changed somewhat between 1932, when he wrote Martial Law, Yesterday and Today, and 1948, when he published the third, revised edition of his classic The President: Office and Powers. ${ }^{164}$ Corwin repeatedly stressed the importance of the Militia Acts with respect to "military power in law enforcement."165 Corwin was, however, just as forceful-if not more so-in his contention that Neagle, along with Debs, presupposed President Theodore Roosevelt's so-called "stewardship" theory-that huge sources of emergency power inherently belonged to the Executive. ${ }^{166}$ Further, though Corwin discussed each of the Militia Acts and even considered the effects of some of the changes in language, he never drew out the specific implications of the 1807 Insurrection Act, nor did he compare the statutory evolution to the development of doctrine in the

160. Id. at 98 .

161. Id. at 99-100 ("Unmistakably the advantage lies with the earlier rather than the later precedent.").

162. Id. at 102 .

163. Id. at 103.

164. CORWIN, supra note 16.

165. Id. at $160,160-70$.

166. Id. at $182-93$. 
courts. ${ }^{167}$ Corwin did not reject the idea that the Militia Acts created broad congressional emergency power that Congress had delegated to the President-he largely overlooked it. In one key passage, Corwin exacerbated the interpretive mistake he first made in his 1932 essay:

The President's powers in relation to martial law were first dealt with by the Court during the Civil War, in the famous Prize Cases. It was there held that the President, by virtue of his power as chief executive and his power as Commander-in-Chief, was entitled to treat a region known to be in insurrection as enemy country and thereby strip all of its inhabitants of their constitutional rights. The case thus ascribes to the President alone the power which in Luther $v$. Borden is attributed to government as a whole... ${ }^{168}$

This conclusion is not wrong per se, but it misconstrues the Prize Cases in a critical way-the President alone may have had such power, but not because the Constitution gave it to him "by virtue of his power as chief executive and his power as Commander-in-Chief." The Prize Cases unequivocally held that this authority belonged to President Lincoln by virtue of the 1795 and 1807 Militia Acts, and Corwin's construction to the contrary helps to explain how, though he was well aware of the Acts, he paid such little attention to their centrality to presidential emergency power or to the specifics of any of the individual statutes.

Similarly, Charles Fairman, an even stronger proponent of broad executive power during World War II-and, to his historical discredit, a fairly strong supporter of President Franklin Roosevelt's authority to hold Japanese Americans in internment camps ${ }^{169}$ — was also committed to a flawed reading of the precedents. Fairman, who today is better known for his canonical take on the question of extraterritorial constitutional rights, ${ }^{170}$ wrote repeatedly throughout his career on martial law and emergency. ${ }^{171}$ Of most significance, however, is the second edition of The Law of Martial Rule, which he published in 1943. ${ }^{172}$

In The Law of Martial Rule, Fairman reached a number of the same conclusions as Corwin with respect to presidential authority and martial

167. Id. at $160-65,174-75$.

168. Id. at $174-75$ (endnote omitted).

169. See Harry N. Scheiber \& Jane L. Scheiber, Bayonets in Paradise: A Half-Century Retrospect on Martial Law in Hawai 'i, 1941-1946, 19 U. HAW. L. REV. 477, 533-34 (1997).

170. Charles Fairman, Some New Problems of the Constitution Following the Flag, I STAN. L. REV. 587 (1949).

171. See, e.g., Charles Fairman, The Law of Martial Rule and the National Emergency, 55 HARV. L. REV. 1253 (1942); Charles Fairman, The Supreme Court on Military Jurisdiction: Martial Rule in Hawaii and the Yamashita Case, 59 HARV. L. REV. 833 (1946).

172. FAIRMAN, supra note 16. 
law. In section 31 of his treatise, Fairman surveyed the Militia Acts and their centrality to the constitutional allocation of the emergency war power before moving on to the Prize Cases. ${ }^{173}$ Under his reading of the Civil War decision, "the Court held that the decision of the President was not reviewable, that by virtue of his proclamation war existed in a legal sense, placing the inhabitants of the territory outside the constitutional protections." 174 As he framed the issue that was before the Prize Cases Court, "the Supreme Court had to ... decide whether the President, in the absence of any declaration by Congress, was competent to recognize the existence of a state of war." 175

Again, however, Fairman neglected to explain the derivation of President Lincoln's authority. Fairman also separated his discussion of Mott and Luther from his discussion of the Prize Cases $^{176}$ and, in so doing, neglected the consistency of the Court's emphasis of the Militia Acts when discussing presidential emergency power.

Indeed, Fairman mentioned the Militia Acts on numerous occasions, but he never really addressed their import-certainly not to the extent that Corwin did. Instead, Fairman's project was more to survey the law of martial rule, rather than to comment on the sources of authority thereto. Where he concerned himself with the sources of such emergency power, Fairman generally deferred to the Executive, without seizing on the Militia Acts as an important source of authority, despite the Supreme Court's statements in Mott, Luther, and the Prize Cases suggesting the opposite.

One (and perhaps the best) counterargument about the Prize Cases and their role in supporting this Note's thesis was implicitly suggested by Corwin $^{177}$ and explicitly highlighted by Farber, and merits consideration here. As Professor Farber put it, "What was important was Lincoln's power, without specific approval by Congress, to engage in what was in fact a war. ... The Framers understood the president to have the power to make war in response to attack, though not necessarily to initiate it without authorization from Congress." 178 Here, Farber refers to the debate at the Philadelphia Convention about whether to give Congress the narrower power to "declare war" or the broader power to "make war."179 This

173. Id. § 31 , at $118-21$.

174. Id. $\$ 31$, at 119; see also supra note 129 and accompanying text (quoting and discussing the passage from the Prize Cases on which Fairman relied).

175. FAIRMAN, supra note $16, \S 31$, at 119 .

176. Compare id. $\S 31$, at 119-20, with id. $\S 28$, at $99-107$ (discussing the other cases).

177. See CorWIN, supra note 16 , at 174-75.

178. FARBER, supra note 3, at 141.

179. See Massachusetts v. Laird, 400 U.S. 886, 893 n.1 (1970) (Douglas, J., dissenting from denial of motion for leave to file bill of complaint) ("The change from 'make' [war] to 'declare' [war] was intended to authorize the President the power to repel sudden attacks ...."). 
argument, more about the defensive war power than about presidential emergency power generally, draws support from the omission of "invasion" from the 1807 Insurrection Act. But invasions are a very specific type of threat. Leaving aside the inconsistencies in the reading of the Prize Cases, the contention that the power to repel invasions is necessarily inherent in Article II both ignores the plain language of the First Militia Clause and also fails to provide any support for broader arguments about inherent presidential authority during emergencies besides invasions.

Regardless, this lacuna concerning the constitutional source of the defensive war power is merely a sidebar. It stands to reason that, were there no statute authorizing presidential use of force to repel an invasion, the Prize Cases might well be read for the proposition that the President has an obligation to defend the nation that transcends separation-of-powers concerns. But the power to repel invasions was not before the Prize Cases Court-the Court was concerned only with the power to impose a blockade, and the first critical passage of Justice Grier's opinion for the Prize Cases Court indisputably holds that President Lincoln could act without "specific" legislative approval not because of his independent constitutional authority, but because broader congressional authorization came from the Militia Acts. ${ }^{180}$

\section{B. Steel Seizure, the Misunderstanding, and Emergency Power Today}

All told, then, Corwin and Fairman, the two most prominent midcentury scholars on presidential emergency power, discussed the Militia Acts (Corwin extensively so), but both fundamentally and critically misread the Prize Cases by focusing on the nature, and not the source, of the authority the Court suggested President Lincoln properly possessed and exercised. Because of the Prize Cases and Corwin's writings, one of two things had (and has) to be true with respect to presidential authority to impose martial law and to invoke the defensive war power: Either the entire source of such power is the regime created by the Militia Acts, or, under the stewardship theory, such power is "inherently" presidential, per cases like Neagle and Debs. This is why the misreading of the Prize Cases is so critical. But for the Prize Cases, it would be a fair reading of Neagle, Debs, and their progeny that the President, as Chief Executive, has all forms of inherent power essential to his office. But one of the key paragraphs from the Prize Cases, though it is rarely cited, suggests precisely the contrarythat the President has broad authority during emergencies, but that such authority is most pointedly not "inherent." 
This point is significant. Most scholars and courts writing after Corwin and Fairman cited one or the other (or borrowed their conclusions without attribution) for the proposition that the President has numerous forms of inherent emergency power, sometimes even including powers explicitly vested in the First Militia Clause. ${ }^{181}$ Because of the stewardship theory, most writers since Corwin and Fairman have started their analysis of emergency power from the perspective that it generally belongs to the Executive and that Congress's authority to legislate about emergencies must be construed in light of this constitutional "grant."

Following to its natural conclusion the argument of scholars who have adopted the stewardship theory, except where Congress has specifically provided statutory authority (and imposed limits) in certain classes of emergencies-for example, via the National Emergencies Act (NEA), ${ }^{183}$ the Stafford Act of 1974, ${ }^{184}$ the War Powers Resolution, ${ }^{185}$ and other assorted statutes $^{186}$ - or except where Congress has explicitly prohibited specific presidential actions during emergencies, ${ }^{187}$ the President's emergency power should be generally unrestrained, falling, at bottom, into Justice Jackson's "zone of twilight" from Steel Seizure. ${ }^{188}$

But this understanding of presidential emergency power is simply not reconcilable with Mott, Luther, and the Prize Cases, for it ignores the contribution of the Militia Acts. Indeed, per Justice Jackson's delineation of executive power in Steel Seizure, as reaffirmed by then-Justice Rehnquist in

181. See, e.g., sources cited supra note 7.

182. The best contemporary example is Judge Wesley's dissent from the Second Circuit's recent decision in the Padilla case. For a discussion, see supra note 128.

183. Pub. L. No. 94-412, 90 Stat. 1255 (1976) (codified as amended at 50 U.S.C. $\S \S 1601-$ $1651(2000))$.

184. Robert T. Stafford Disaster Relief and Emergency Assistance Act of 1974, Pub. L. No. 93-288, 88 Stat. 143 (codified as amended in scattered sections of 42 U.S.C.).

Importantly, the Stafford Act is a much broader grant of authority than what may first appear. As Paul Schott Stevens writes, "[T]he statute even grants the president the authority to utilize [the Department of Defense] on an emergency basis for 10 days prior to a presidential declaration of a major disaster or emergency.... The president first must determine that the DOD actions are necessary to preserve life and property." STEVENS, supra note 7, at $18 \mathrm{n} .76$ (citing 42 U.S.C. $\$ 5170 b(c)(1)(1994))$.

185. War Powers Resolution of 1973, Pub. L. No. 93-148, 87 Stat. 555 (codified at 50 U.S.C. $\S \S 1541-1548(2000))$.

186. For a summary of other relevant statutes, see STEVENS, supra note 7, at 17-19.

187. See, e.g., Non-Detention Act of 1971, Pub. L. No. 92-128, § 1, 85 Stat. 347, 347 (codified at 18 U.S.C. $\S 4001$ (a) (2000)). As I have recounted elsewhere, $\S 4001$ was enacted as much to repudiate Roosevelt's actions during World War II as it was to specifically repeal the Emergency Detention Act of 1950, Pub. L. No. 81-831, tit. II, 64 Stat. 987, 1019 (repealed 1971). See Vladeck, supra note 13, at 178-80; Stephen I. Vladeck, Policy Comment, $A$ Small Problem of Precedent: 18 U.S.C. $\$ 4001(a)$ and the Detention of U.S. Citizen "Enemy Combatants," 112 YALE L.J. 961 (2003).

188. Youngstown Sheet \& Tube Co. v. Sawyer (Steel Seizure), 343 U.S. 579, 637 (1952) (Jackson, J., concurring). 
Dames \& Moore v. Regan, ${ }^{189}$ presidential emergency actions involving the military at home are either pursuant to express congressional authorization or they are a usurpation of Congress's emergency power. The former falls into Jackson's first category, the zenith of presidential power; ${ }^{190}$ the latter falls into the third category, where the President's power is "at its lowest ebb." ${ }^{\prime 191}$ For courts attempting to analyze and assess presidential actions in a crisis after the next emergency, this interpretive metric should be the starting point.

Indeed, our contemporary regime of domestic emergency power, as structurally preserved in the NEA, is predicated on specific statutes authorizing the use of emergency powers, including those discussed above and countless others. As section 201 of the NEA dictates, the President's power to declare national emergencies is only "[w]ith respect to Acts of Congress authorizing the exercise, during the period of a national emergency, of any special or extraordinary power." 192 The importance of the Militia Acts, as presently codified at 10 U.S.C. $\S \S 331-335$, is that they constitute a significant source of presidential emergency power that may be invoked under the NEA, but one with little in the way of substantive delineation. Their application and interpretation are largely up to the presidents who resort to them.

\section{CONCLUSION}

But why does this matter? If Congress has delegated all of its authority under the First Militia Clause to the President, as the Militia Acts clearly suggest, why should contemporary scholars care about the constitutional source of such power? The answer is that whatever power the President currently possesses to declare and impose a state of martial law in an emergency is ill defined-there would be few, if any, limits governing the imposition of martial law in a true domestic emergency, as, for example, in the hypothetical from The Siege that this Note opened with.

Indeed, as this Note has shown, it is manifestly unclear whether courts could have any role in policing the actions of a future President in

189. 453 U.S. 654 (1981).

190. Steel Seizure, 343 U.S. at 635-37 (Jackson, J., concurring).

191. Id. at 637-38. Importantly, congressional silence, normally an indicator for Jackson's "zone of twilight," see id. at 637 , would mean more in this context, given the extent of congressional emergency delegations elsewhere in the field. Further, and this point bears emphasizing, the focus here is on domestic emergency authority and not any adjunct of the foreign affairs power. Justice Jackson highlighted this distinction as a key consideration in Steel Seizure, see id. at 644, and contemporary courts have emphasized this point in distinguishing extraterritorial presidential emergency actions from domestic ones, see, e.g., El-Shifa Pharm. Indus. Co. v. United States, 378 F.3d 1346, $1369-70$ (Fed. Cir. 2004).

192. National Emergencies Act (NEA) § 201(a), 50 U.S.C. $\S 1621$ (a) (2000). 
responding to a serious crisis, and it is just as unclear what specific powers the President has by virtue of the Militia Acts, what specific actions are foreclosed to him, and where the gray area is with regard to triggers for various levels of authority.

This Note's reading of the Militia Acts suggests that the President would have broad authority to respond to a crisis (that it is his prerogative to determine exists) by declaring martial law and suspending civil authority. The lessons of history teach that if Congress is so inclined, it will enthusiastically support the President, whether through its silence or through affirmative ratification. But what if Congress disagrees? What if Congress cannot assemble? ${ }^{193}$ What role for the courts then? Whether for logistical or political reasons, it may be impossible for Congress to assert itself forcefully (as the Militia Acts clearly suggest it could) after the next emergency. The optimum solution to the vagaries of the current regime, then, is a comprehensive update of the Militia Acts now.

Perhaps the early form of the Militia Acts, as discussed above, provides a useful and usable paradigm for this kind of emergency power legislation. Granting the President broad power, but only until Congress can reassemble, is as reasonable as it is practical. As was the case during the Whiskey Rebellion, requiring congressional reauthorization within thirty days of the commencement of the next legislative session allowed for coordination between the two branches and prevented resort to extraordinary measures if the two disagreed. ${ }^{194}$ No such checks exist today. True, Milligan holds that martial law is available only where the courts are closed or their process obstructed, but one means of accomplishing either is to impose martial law itself. Who would be left to object?

If we assume, for the sake of argument, that explicit demarcation of the authority the President may exercise in an emergency is a bad idea (because the most dangerous crisis is the one whose contours no one expects), general principles regarding time and scope can and should be derived from the original emergency regime set up by the Second and Third Congresses. To prevent potential excesses and abuses, some modification of the Militia Act regime, as presently codified, is necessary. Such amendment could take the form of an outright time limit on general executive action in response to an emergency, once one is declared under the NEA, or it could be more

193. For a discussion of some of these concerns, see Howard M. Wasserman, The Trouble with Shadow Government, 52 EMORY L.J. 281 (2003). See also Glenn E. Fuller, Note, The National Emergency Dilemma: Balancing the Executive's Crisis Powers with the Need for Accountability, 52 S. CAL. L. REV. 1453 (1979).

194. See supra notes $48-49$ and accompanying text. Indeed, this kind of coordination is at the heart of Professor Bruce Ackerman's broad proposal for a new framework emergency statute, see Ackerman, Emergency Constitution, supra note 8, which would require increasing supermajorities from Congress to sign off every so often on the continued exercise of "emergency" powers. 
specifically fitted to the type of emergency, distinguishing (as Canada does, ${ }^{195}$ for example) between terrorism and natural disasters, war and peace. In either event, the statutory regime unquestionably needs more crystallization of the scope of each of the different levels of authority, and the necessary triggers for each level.

As one commentator wrote in 2000 , "The circumstances that would prompt a declaration of martial law are so horrendous that they are almost beyond contemplation. But that dreadful eventuality should not translate into a lack of preparation, for if the nation is prepared, it is less likely to fear even the most awful possibilities." ${ }^{\text {"196 }}$ After September 11, with such circumstances no longer "beyond contemplation," it is even more important that such crisis authority have limits and that Congress reassert its constitutional role - and, indeed, its obligation - in imposing them.

195. Emergencies Act, R.S.C., ch. 22, §§ 5-45 (Supp. IV 1985) (Can.).

196. Davies, supra note 2, at 112. 